Bond University

Research Repository

\title{
The epidemiology of injuries across the weight-training sports
}

Keogh, Justin W L; Winwood, Paul W.

Published in:

Sports Medicine

DOI:

10.1007/s40279-016-0575-0

Licence:

Other

Link to output in Bond University research repository.

Recommended citation(APA):

Keogh, J. W. L., \& Winwood, P. W. (2017). The epidemiology of injuries across the weight-training sports. Sports Medicine, 47(3), 479-501. https://doi.org/10.1007/s40279-016-0575-0

\section{General rights}

Copyright and moral rights for the publications made accessible in the public portal are retained by the authors and/or other copyright owners and it is a condition of accessing publications that users recognise and abide by the legal requirements associated with these rights.

For more information, or if you believe that this document breaches copyright, please contact the Bond University research repository coordinator. 
Weight training injuries

THE EPIDEMIOLOGY OF INJURIES ACROSS THE WEIGHT TRAINING SPORTS: A SYSTEMATIC REVIEW

Corresponding Author

Justin W.L. Keogh PhD

Bond University

Faculty of Health Sciences and Medicine

Gold Coast

Australia

Tel: +61 755954487

Fax: +61 755954480

Email: jkeogh@bond.edu.au 
The Epidemiology of Injuries across the Weight Training Sports: A Systematic Review

Running head: Injuries in weight training sports

\section{Authors:}

Justin W. L. Keogh ${ }^{1,2,3}$ and Paul W. Winwood ${ }^{2,4}$.

${ }^{1}$ Bond University

Faculty of Health Sciences and Medicine

Gold Coast

Australia

\section{${ }^{2}$ AUT University}

Sports Performance Research Institute New Zealand (SPRINZ)

AUT Millennium

Auckland

New Zealand

${ }^{3}$ University of the Sunshine Coast

Faculty of Science, Health, Education and Engineering

Queensland

Australia

${ }^{4}$ Bay of Plenty Polytechnic

Department of Sport and Recreation

School of Applied Science 
Weight training injuries

Tauranga

New Zealand 
Weight training injuries

\section{Key Points}

The weight training sports appear to have lower rates of injury than many common team sports. It is however acknowledged that this conclusion may partly reflect some limitations in the weight training sport injury epidemiology literature, primarily study design, diagnosis of injury and changes in risk exposure.

Each of the weight training sports tended to have some subtle differences in their injury epidemiology, particularly their proportional injury rates across the various anatomical locations as well as the onset and severity of injury.

The intrinsic factors of sex, competitive standard, age and bodyweight class may only have a relatively minor influence on the injury epidemiology of the weight training sports. 
Weight training injuries

\section{Abstract}

Background: Weight training sports including weightlifting, powerlifting, bodybuilding, strongman, Highland Games and CrossFit are weight training sports that have separate divisions for males and females of a variety of ages, competitive standards and bodyweight classes. These sports may be considered dangerous due to the heavy loads commonly used in training and competition. Objectives: To systematically review the injury epidemiology of these weight training sports; and where possible gain some insight into whether this may be affected by age, sex, competitive standard and bodyweight class. Methods: An electronic search was performed using PubMed, SPORTDiscus, CINAHL and Embase for injury epidemiology studies involving competitive athletes in these weight training sports. Eligible studies included peer-reviewed journal articles only, with no limit placed on date or language of publication. Risk of bias was assessed in all studies using an adaption of musculoskeletal injury review method. Results: Only five of the 20 eligible studies had a risk of bias score $\geq 75 \%$; meaning the risk of bias in these five studies was considered low. While 14 of the studies had sample sizes greater in 100 participants, only four studies utilized a prospective design. Bodybuilding had the lowest injury rates (0.12 0.7 injuries per lifter per year; 0.24 - 1 injury per 1000 hours), with strongman (4.5 - 6.1 injuries per 1000 hours) and Highland Games (7.5 injuries per 1000 hours) reporting the highest rates. The shoulder, lower back, knee, elbow and wrist/hand were generally the most commonly injured anatomical locations; with strains, tendinitis and sprains the most common injury type. Very few significant differences in any of the injury outcomes were observed as a function of age, sex, competitive standard or bodyweight class. Conclusion: While the majority of the research reviewed utilized retrospective designs, the weight training sports appear to have relatively low rates of injury compared to common team sports. Future weight training sport 
injury epidemiology research needs to be improved, particularly with regard to the use of prospective designs, diagnosis of injury and changes in risk exposure.

\section{Introduction}

Weight training is a popular physical activity that is typically performed to increase muscular hypertrophy, strength and endurance. Weight training typically uses the force of gravity acting upon resistances including the exerciser's own bodyweight or specialized forms of equipment such as barbells, dumbbells and resistance training machines to target specific muscle groups and joint actions. While many people who regularly exercise perform weight training along with cardiovascular or flexibility exercise for overall health benefit, several athletic groups also compete in sports in which weight training is the primary form of training and/or the competitive event. These sports include weightlifting, powerlifting, bodybuilding, strongman, Highland Games and CrossFit.

Weightlifting requires the lifter to lift maximal loads for one repetition in two exercises; the clean and jerk and the snatch. As these exercises require the barbell to be lifted explosively from the floor to an overhead position, they may produce the greatest power outputs of any human activity [1]. Up until 1972, weightlifting also involved a third lift, the overhead (shoulder) press. Powerlifting is similar to weightlifting, with lifters attempting to lift the maximum loads for one repetition. However, in powerlifting competitions the three lifts performed are the squat, bench press and deadlift.

The Scottish Highland Games and strongman competitions are in some ways, the most similar form of weight training competition to that done in ancient or medieval times, with some of the 
Weight training injuries

events found in the sports traditionally performed as tests of manhood in many countries. These tests of manhood typically had farming and/or military applications and involved the lifting or throwing of a variety of natural and man-made objects that have been available for hundreds or thousands of years. Specifically, strongman events utilize a variety of heavy implements such as stones for lifts and carries, tyres for flipping, logs and stones for overhead pressing and trucks or sleds for pulling. While some of these strongman events are similar to weightlifting and powerlifting with the athletes attempting to lift the heaviest load for one repetition, many of the events are timed with the winner being the fastest athlete to complete the task. Highland Games events are other ancient/mediaeval examples of tests of manhood and typically involve a range of heavy throwing events such as the caber, stone put, hammer throw or sheaf toss as well as weight for height and distance. The variety of weight for distance events are simply much heavier versions of many of the throwing events currently seen in regular track and field competitions.

CrossFit is the newest of the weight training sports. CrossFit programs, known as 'workouts of the day' (WODs), typically exceed 10-20 minutes and include a variety of bodyweight and resistance exercises, gymnastics, weightlifting, powerlifting, and endurance activities. These exercises are generally combined into high-intensity workouts that are performed in rapid succession with limited or no recovery time. CrossFit athletes also compete in the CrossFit games where the winner is decided by the athlete who completes the WOD in the shortest period of time.

Bodybuilding differs from the other weight training sports in that it is not judged on the weight lifted or the time taken to complete an event, but rather on the physical appearance of the athlete. Bodybuilding competitors therefore also perform regular high intensity weight training to 
Weight training injuries

develop muscle bulk, balance between muscle groups (symmetry), muscular density and definition, as these are the criteria they are judged on in competition.

Most of these weight training sports included in this review have annual world championship events for male and female athletes, with some of these sports also offering various bodyweight or age (Junior, Open and Masters) classes. However, weightlifting is the only one of these sports currently included in the Olympic Games, although powerlifting (bench press only) is also a part of the Paralympics. A picture of some common weight training exercises performed by the athletes competing in the sports is provided in Figure 1.

\section{PLEASE INSERT FIGURE 1 about here}

Due to the intense, heavily loaded activities commonly performed by these athletes in training and competition, the joint moments (torques) as well as shear and compressive forces produced during these types of exercises can be very large [1-5]. Members of the public, sporting, medical and scientific communities may therefore believe these activities are inherently dangerous and their performance will result in numerous serious and/or long-term injuries. Such a view may also reflect the many case-studies found in the literature in which needless weight training-

related severe injuries $[6,7]$ and catastrophic incidents have been reported $[8,9]$. According to the National Center for Catastrophic Sport Injury Research [10], catastrophic injuries can be defined as "fatalities, permanent disability injuries, serious injuries (fractured neck or serious head injury) even though the athlete has a full recovery, temporary or transient paralysis (athlete has no movement for a short time, but has a complete recovery), heat stroke due to exercise, or sudden cardiac arrest or sudden cardiac or severe cardiac disruption.” While these case studies 
highlighting the risks of weight training are important to acknowledge, the primary objective of this analysis was to systematically review the injury epidemiology of these weight training sports using a list of injury epidemiology outcomes advocated by the International Olympic Committee (IOC) [11]. The secondary objective was to gain some insight into whether demographic characteristics such as age, sex, competitive standard and bodyweight class influenced the injury epidemiology of these weight training sports.

\section{Methods}

\subsection{Search Strategy and Inclusion Criteria}

No review protocol for this paper currently exists, although this manuscript is an update of a previous literature review published as a chapter in a 2009 IOC text on sporting injury [12]. The original book chapter included 10 journal articles (all of which are cited in the current review) as well as two abstracts. Neither of these abstracts was deemed eligible for this current review, as neither contained sufficient detail to determine their risk of bias (ROB). As a result of the increased research into weight training injury and the emergence of CrossFit and to a lesser extent strongman as new participation sports since the previous book chapter, the authors believe such an update has considerable merit.

A search was conducted using PubMed, CINAHL, SPORTDiscus and Embase up to the $15^{\text {th }}$ of September 2015. As the focus was on quantifying the injury epidemiology of the weight training sports, a three level approach was utilized. The first level involved using derivatives of the terms injury, weightlifting, powerlifting, bodybuilding, strongman, Highland Games and CrossFit so to identify injury studies involving these sports. The second level meant that the studies had to utilize an injury epidemiology rather than case study design. The third level required the studies 
to contain key words relating to injury which included; wound, rupture, sprain, strain and tear. The full search strategy for the PubMed search was ((injur*[Text Word] OR rupture*[Text Word] OR sprain*[Text Word] OR strain*[Text Word] OR tear*[Text Word]) OR "Wounds and Injuries"[Mesh]) AND ("Weight Lifting"[Mesh] OR weight lift*[Text Word] OR weightlift*[Text Word] OR power lift*[Text Word] OR powerlift*[Text Word] OR body build*[Text Word] OR bodybuild*[Text Word] OR strongman[Text Word] OR "strong man"[Text Word] OR "Highland Game"[Text Word] OR "Highland Games"[Text Word] OR "Cross fit"[Text Word] OR CrossFit[Text Word])) AND (injur* AND weight lift* OR weightlift* OR power lift* OR powerlift* OR body build* OR bodybuild* OR strongman OR strong man OR Highland Game OR Crossfit OR CrossFit).

To be included in this review, the studies had to be full peer-reviewed journal articles that contained a description of the injury epidemiology of at least one of the weight training sports. Articles in any language were accepted, with this resulting in the inclusion of 15 articles written in English along with two Chinese, two German and one Korean article. As neither of the two authors were able to read Chinese, German or Korean, the authors sought the assistance of one Chinese colleague, one German colleague and Google Translate to assist in the translation of these articles, respectively. The two authors provided their Chinese and German colleagues with sufficient assistance to quantify the risk of bias and to extract the relevant information for the systematic review, as performed by the two authors on the remaining 16 papers.

No restrictions were placed on the year of publication and no effort was made to contact any of the study authors to identify additional studies. All of these studies involved adults, except Brown and Kimball [13] who examined the retrospective injury epidemiology of 71 adolescent 
Weight training injuries

powerlifters aged 14-19 years. For those interested in a more in-depth discussion on the injury risk of weight training for children, the reader should consult any of the following review articles [14-16].

After removal of duplicate studies, all study titles were screened by two independent reviewers (JK and PW). All potentially eligible articles were retrieved in full-text and evaluated for eligibility by the same reviewers (authors). Reference lists of these articles were also scanned for other potentially relevant articles that were not initially identified in the database searches. All included article titles were then tracked forward by citation tracking using Google Scholar to find any other potentially relevant articles that could be included in the review. Any disagreements between the two authors regarding the inclusion of studies within this review were resolved in a consensus meeting.

\subsection{Risk of Bias Assessment and Data Extraction}

The ROB of the eligible studies was assessed by both authors (and where relevant the Chinese and German colleagues) independently using a checklist (Electronic Supplementary Material Table S1) developed for assessing the ROB in studies examining musculoskeletal injury [17-19]. Any disagreements between the two authors regarding the ROB of the eligible studies were resolved in a consensus meeting. The results of the bias assessment are displayed in Table 1. All items were scored as positive (+) or negative (-) for studies with a low and high ROB, respectively. When no clear information regarding the item was given or when it was unclear whether the ROB criteria for an item was met, the item was scored as negative. The total ROB score for each study was calculated by counting the number of items that were scored positively, 
Weight training injuries

expressed as a percentage of all items. Articles with a ROB score $\geq 75 \%$ were considered as having a low ROB [19].

PLEASE INSERT TABLE 1 about here

\subsection{Data Analysis}

Consistent with the IOC recommendations [11], the data from the included epidemiology studies was categorized into the following primary sections: Who is affected by injury?; Where does injury occur?; When does injury occur?; What is the outcome?; What are the risk factors?; and What are the inciting events. Where data were reported for specific demographic groups based on age, sex, competitive standard or bodyweight class, results for these additional sub-group analyses were also reported. The primary variable of interest was injury rates which were reported in two ways; 1) injury per athlete per year; and/or 2) injury per 1000 hours of exposure where possible. Within each of the result sections, a discussion of the results has also been provided. This was done as the authors felt this approach made for an easier integration of the large amounts of data presented and their potential interpretations, applications and limitations.

\section{Results and Discussion}

\subsection{Literature Search}

An examination of 4021 titles (including 411 duplicates) revealed 184 potentially relevant fulltext articles which were retrieved. After review of the full-text, a further 167 articles were excluded. The 17 eligible studies were then reviewed, with their reference lists also checked to identify other potentially eligible studies that may have been missed in the initial search. This process revealed another two eligible studies, resulting in a total of 19 studies. The 19 studies 
Weight training injuries

were then forward tracked in time by citation tracking using Google Scholar in which one more study was found resulting in a total of 20 studies in this review. A pictorial representation of the literature search is presented in Figure 2.

\section{PLEASE INSERT FIGURE 2 about here}

Within the 20 eligible studies, data were presented for weightlifting (eight studies) and powerlifting (six studies). Four studies for bodybuilding, one study of strongman, one study of Highland Games and two studies for CrossFit injury epidemiology were also identified. There was often considerable intra- and/or inter-study variation in the age, sex, body mass and standard of the lifters, with a small number of the studies reporting data for these sub-groups. Specifically, several studies categorized (at least some of) their data by sex [20-24], competitive standard [20, 23, 25, 26], age [20, 26] and bodyweight class [20, 26].

\subsection{Risk of Bias}

The results of the ROB assessment are displayed in Table 1. Five of the 20 studies had a score $\geq 75 \%$ and were considered to have a low ROB [19]. The definition of injury was clearly described in 14 studies [13, 20, 22, 24-34], with these definitions typically requiring an injury to involve physical damage to the athlete that caused the athlete to modify or cancel at least one training session. A summary of the definitions provided in these papers is provided in Table 2. Four of the included studies used a prospective design [22, 24, 27, 28]. Three studies did not clearly describe the participants’ competitive level and/or demographic characteristics [33, 35, 36]. Fourteen studies used subject sample sizes $\geq 100$ [20-23, 25, 26, 28, 30, 32-34, 36-38]. The criteria for the inclusion of participants (i.e. random or the data collection was performed with 
Weight training injuries

the entire target population) was clear in eight studies [13, 22-24, 27-29, 37]. Only one of the 20 studies' data analysis did not represent at least $80 \%$ of the included participants [32]. Seven studies employed an appropriate duration of data collection [20, 24-27, 29, 34]; (i.e. for prospective studies at least a 6-month follow up, for retrospective studies up to a 12 month recall period). One study used different modes of data collection [20] (e-mail, telephone, interview, etc.). A diagnosis of all injuries was conducted by health professionals in five studies [22, 24, 2729] and partially in another five studies [13, 20, 21, 26, 31]. Changes in risk exposure (e.g. seasonal changes, training versus competition) were taken into account in six studies [22-24, 26, 28, 37]. Eleven studies reported number of injuries by exposure time to weight training [20, 2427, 29-33, 38].

PLEASE INSERT TABLE 1 about here PLEASE INSERT TABLE 2 about here

\subsection{Who Is Affected By Injury?}

Injury incidence rates reported in Table 3 were somewhat consistent, with most studies reporting $\sim 1$ - 2 injuries per lifter per year or $\sim 2$ - 4 injuries per 1000 hours. However, there were some exceptions to this rule. Studies reporting lower injury rates included three bodybuilding studies (0.12 - 0.7 injuries per lifter per year or 0.24 - 1 injury per 1000 hours) $[21,31,38]$ and two of the six powerlifting studies (0.3 - 0.4 injuries per lifter per year and $1.0-1.1$ injuries per 1000 hours) $[29,30]$. Studies reporting higher injury rates included the only studies on strongman (2.0 injuries per lifter per year and 5.5 injuries per 1000 hours of training) [26] and Highland Games (7.5 injuries per 1000 hours of training and competition) [32]. 
The manner in which the injury incidence rate data was presented for the weightlifting study of Kim and Kim [24] precluded direct comparison of the other studies. While Kim and Kim [24] reported injuries per 1000 athlete exposures, they did not normalize their data to the number of weightlifters nor provide the number of weightlifters included in this study. Therefore, it was not possible to determine the number of injuries per lifter per year or the number of injuries per 1000 hours as presented in previous studies.

\section{PLEASE INSERT TABLE 3 about here}

As only one study was found for the sports of strongman and Highland Games, it is difficult to be certain that these sports have a greater injury risk compared to the other weight training sports. Winwood et al. [26] did however quantify injury rates associated with different types of strongman training, reporting that although only $31 \%$ of strongman training involves specific implement (event) training, implement training accounted for 1.9 times more injury than traditional training (e.g. squat, deadlift, bench press etc.) when normalized by time of exposure. Such results may indicate that strongman exercises by the nature of their dynamic movements may involve somewhat higher injury risk than traditional weight training exercises performed with barbells, dumbbells or weight training machines.

A number of the studies also reported the athlete injury rate (i.e. the proportion of athletes who had suffered an injury [22, 23, 28, 30, 31, 34], with this varying from 16 - 90\%. Drawing comparisons between these studies is difficult as the time frame of data collection differed. At one extreme, Junge et al. [28] and Engebretzen et al. [22] collected data during Olympic competitions (16 and 17 days, respectively), whereas other studies [30, 31] collected data over 
Weight training injuries

the athletes' entire career. In contrast, Wang et al. [23] provided no specific timeframe for the duration of the data collection.

\subsection{Where Does Injury Occur?}

\subsubsection{Anatomical Location}

Inspection of the individual studies revealed that the five most commonly injured sites were typically the shoulder, lower back, knee, elbow and wrist/hand across the weight training sports (see Table 4). Almost all of these data were reported as percentage of overall injuries, with Raske and Norlin [25] and Kim \& Kim [24] the only studies to also report incidence rates for each anatomical location. The finding that shoulder injuries accounted for a high percentage of all weight training sports injuries in the studies (6 - 36\%) may reflect the frequent use of heavy loads and exercises such as the bench press and overhead presses (e.g. strict press, push press or jerk) by these athletes. Kobler and colleagues [39] suggested that the susceptibility of the shoulder complex to weight training injury is in part due to the high compressive loads these exercises apply to a traditionally non-weight bearing joint. Furthermore, the bench and overhead presses may place the shoulder in somewhat unfavorable positions, such as end-range external rotation while under heavy loads, predisposing the shoulder to both acute and chronic injuries $[39,40]$.

PLEASE INSERT TABLE 4 about here

There were some subtle between-sport differences in the most common sites of injury. In descending order, the three most frequent injury sites appeared to be: weightlifting (knee, lower back and shoulder); powerlifting (shoulder, lower back and knee); bodybuilding (shoulder, knee 
and lower back); strongman (lower back, shoulder and bicep); Highland Games (shoulder, knee and lower back); and CrossFit (shoulder, lower back and knee). However, it must be acknowledged that there was some between-study variation in the anatomical location categories and/or definitions utilized in these studies. Further, as anatomical location of injury was only examined in two studies of CrossFit, one study of strongman and one study of Highland Games, further research is required to better characterize the most commonly injured anatomical locations in these sports.

The subtle differences in the most commonly injured anatomical locations for these weight training sports begs the question about what aspects of these sports may alter the most commonly injured body parts (anatomical locations), particularly as athletes in all of these weight training sports often perform similar exercises including squats, power cleans, deadlifts and/or overhead presses. One answer may lie in the different competitive goals and training practices of each of the sports. Typically, weightlifters, powerlifters, strongman and perhaps Highland Games athletes lift heavier loads (at a higher percentage of one repetition maximum (1RM)) for fewer repetitions with longer rest periods between sets than bodybuilders or CrossFit athletes [41-45]. Further, there may often be considerable between-sport differences in the manner in which these exercises are commonly performed that may alter the relative loading and hence injury risk to various anatomical locations.

The possibly higher rate of knee injuries for weightlifters $(10-32 \%)$ compared to the other weight training sports (5 - 28\%) may reflect differences in the manner in which the squat (and their derivatives) are performed by these groups. For example, weightlifters perform the clean and jerk, snatch, front squat and high-bar back squats through a full range of motion whereby the 
gluteals may come to rest on the calf musculature at the bottom of the lift. Such a range of motion and the bar position requires the weightlifter to maintain a vertical trunk position and utilise large degrees of dorsiflexion and anterior knee translation. This contrasts with powerlifters and strongman athletes who typically position the bar further down their back than the other groups during the squat, with this typically referred to as low-bar squat [41, 44]. This low-bar squat results in a greater forward inclination of the trunk at the bottom of the lift than the high-bar / front squat favored by weightlifters [46]. By virtue of these differences in trunk inclination, dorsiflexion and anterior knee translation, the high-bar or front squat has a larger knee resistance moment arm and smaller hip/lower back resistance moment arm than the low-bar squat. Such differences in resistance moment arms suggest that the high-bar or front squat may require greater knee extensor torques and produce greater mean compressive patello-femoral forces than low-bar squats $[2,46]$. Therefore, the lower frequency of knee injuries for some of the weight training sports including powerlifting and strongman compared to weightlifting may reflect the reduced mechanical stress that low-bar squats apply to the knee compared to high-bar or front squats.

Overall, the subtle differences in the most commonly injured anatomical locations of injury for the weight training sports suggests that differences in exercise/event load, selection as well as the actual technique and body positioning in a particular exercise/event can alter the mechanical stress placed on specific anatomical locations and therefore the subsequent injury risk. A detailed analysis of the injury inciting events is outlined in section 3.8. 
Weight training injuries

\subsubsection{Environmental Location}

Only four studies have documented the number of injuries that lifters experienced in competition [22, 24, 26, 28], with many studies combining data from training and competition. Junge et al. [28] found that $90 \%$ of injuries $(n=26)$ reported by weightlifting athletes at the 2008 Summer Olympic Games occurred during competition [22]. This was higher than the $45 \%$ of competition injuries $(n=18)$ reported by weightlifters in the 2012 Summer Olympic Games [22]. In contrast, Kim and Kim [24] reported that $1.5 \%$ of the injuries $(n=3)$ reported by Korean weightlifting athletes over a 271 day period occurred during competition. Winwood and colleagues [26] found that strongman athletes experienced $1.6 \pm 1.5$ training injuries per athlete per year compared to $0.4 \pm 0.7$ competition injuries per athlete per year. While such findings would suggest that the risk of injury in training is greater than in competition, weight training athletes will often train many hours per week but only compete a handful of times per year, meaning the training exposure is substantially greater than that of competition. To address these limitations, future studies should seek to report the training and competition injury data per 1000 hours of training and competition exposure. Such an approach is warranted in that athletes in the weight training sports (with the possible exception of bodybuilding) are generally subjecting their bodies to greater levels of musculoskeletal stress in a competitive rather than training environment.

Three studies also specifically recorded injuries that did not occur as a direct result of weight training [20, 27, 38]. Keogh et al. [20] observed that $13 \%$ and $15 \%$ of the injuries reported by a group of 101 powerlifters resulted from cross-training (e.g. ball sports or cardiovascular training) or were of unknown origin, respectively. Calhoon et al. [27] reported similar results with 36\% of the weightlifting injuries recorded in the United States Olympic Training Centre occurring outside of their regular weightlifting training sessions. In contrast, Eberhardt et al. [38] found 
Weight training injuries

that only $1 \%$ of the injuries reported by 250 bodybuilders occurred during non-weight training activities.

\subsection{When Does Injury Occur?}

\subsubsection{Injury Onset}

As seen in Table 5, there have only been eight studies that have reported data on injury onset in the weight training sports [20, 22-28], with these studies conducted on weightlifting, powerlifting and strongman athletes. These studies reported the onset for all injuries collectively with no injury onset data given for each anatomical location. While most of these studies recorded acute and chronic injuries, there were a number of exceptions. Two weightlifting studies only reported chronic injuries [28, 38], one weightlifting study only reported acute and recurrent injuries [24] and Keogh et al. [20] also incorporated acute-to-chronic or "other” onset categories. With the exception of Wang et al. [23] and perhaps Kim and Kim [24], these studies suggest that athletes in weightlifting, powerlifting and strongman experienced a greater rate of acute (26 - 72\%) than chronic (25 - 50\%) onset injuries.

PLEASE INSERT TABLE 5 about here

\subsubsection{Chronometry}

Only two studies have directly examined the chronometry of injury in the weight training sports [26, 37]. Winwood and colleagues [26] found that half (51\%) of the training injuries reported by strongman athletes occurred in the general preparation phase of their yearly training plan. Winwood and colleagues [26] also requested the participants to estimate the time their injuries occurred during training sessions and competitions, via a tertile classification system i.e. early, 
Weight training injuries

mid or late within a training session or competition. The most common time for a training injury was "early" in the training session (36\% of all training injuries), whereas the most common time for competition injury was late in the competition (44\% of all competition injuries) [26]. Xiaojun et al. [37] found that nearly half of all injuries (49\%) reported by bodybuilders occurred in the three months comprising winter, whereas only $9 \%$ of injuries occurred in the three months of summer.

The limited data on chronometry of weight training injuries appears somewhat consistent with aspects of the literature for team sports. Specifically, team sport athletes may suffer more injuries during the final third (15 minutes) of each half of a football (soccer) match and during the preseason than regular season $[47,48]$. Collectively, the results found in the review and that in previous studies of team sports may suggest that fatigue and a lack of “conditioning” are also possible risk factors for injury in the weight training sports [47, 48].

\subsection{What is the Outcome?}

\subsubsection{Injury Type}

Nine studies provided data on the injury type experienced by weight training athletes (see Table 6), with strains, tendinitis and sprains generally the most common across the sports with some minor exceptions. The three most common injury types for these sports were (in descending order): weightlifting (strains, sprains and tendinitis), powerlifting (strains, tendinitis and arthritis), bodybuilding (sprains, tendinitis and cartilage degeneration), strongman (muscle strains, tendon injuries and ligament sprains/tears) and Highland Games (tendinitis, strains and cartilage damage). The results demonstrate that the three sports in which competition and training performance is based on lifting heavier loads than ones competitors (weightlifting, 
Weight training injuries

powerlifting and strongman) have muscle strains as the most common injury type (6 - 62\%). In contrast, bodybuilders who typically train at a lower percentage of 1RM experience a lower proportion of muscle injuries (7 - $34 \%$ ), but report a greater proportion of cartilage (28 - 32\%) and tendon injuries (29 - 63\%). Such results suggest that the greater loads used by powerlifters, weightlifters and strongman athletes predispose them to a higher proportion of acute-type muscle strain injuries; with the greater volume of exercise performed by bodybuilders tending to produce a greater proportion of chronic-type connective tissue injuries.

PLEASE INSERT TABLE 6 about here

\subsubsection{Severity of Injury and Associated Time Loss}

Fourteen studies reported data on the injury severity/time loss associated with injuries, with a summary of these studies provided in Table 7. Two studies (both on powerlifting) reported that the average injury was symptomatic for $\sim 12$ days [13, 29]. A number of other studies also recorded the time that each injury affected training, but reported this in specific time bands such as $<1$ day, 1 - 7 days, 8 - 14 days and $>14$ or 30 days (one month) [22, 25, 27, 32, 35, 36]. With the exception of Raske and Norlin [25], all of the studies reporting data on severity/time loss of injury indicated that the majority of weight training injuries were symptomatic for less than two weeks, a value similar to the two powerlifting studies reporting mean injury durations of 12 days $[13,29]$. Another four studies [20, 23, 26, 37] assessed the time loss by categorizing the effect on the injury had on the athletes' training, with injuries classified as mild (exercise execution required modification), moderate (stopped performing the exercise) or major (training stopped completely for a period of at least a week). In general, these four studies also observed most injuries (78 - 99\%) to be of a mild or moderate severity. 
PLEASE INSERT TABLE 7 about here

\subsubsection{Clinical Outcome}

The clinical outcome of injury can be described using a variety of outcomes including recurrent (repeat) injury, catastrophic incidents, non-participation injury (injuries that force the athlete to retire) and residual effects (injuries resulting in long-lasting or permanent symptoms or disability) [11]. Results of this review indicate there is little clinical outcome epidemiological data specifically determined for the weight training sports.

Winwood and colleagues [26] reported that 115 (44\%) of the 260 injuries reported by strongman athletes over the course of the year were repeated (recurrent) injuries. Kim and Kim [24] reported that 145 (70\%) of the 207 injuries reported by Korean weightlifters were recurrent injuries. In contrast, Kulund et al. [35] reported that only three of the 111 injuries reported by a group of 80 weightlifters were recurrent. Unfortunately, the study of Kulund et al. [35] is limited in that the duration over which data collection occurred was not stated.

Some insight into the potential of the weight training sports to result in non-participation injuries was obtained by Raske and Norlin [25]. Over the course of five years of data collection, it was reported that $38 \%$ of the elite weightlifters and powerlifters retired, with almost half (43\%) of these lifters citing injury as the reason for retiring [25]. Such results may suggest that participation in the weight training sports has the potential to lead to a range of residual effects that may affect these athletes after retirement. This view is supported by the findings that arthritis (3 - $29 \%)$ and cartilage degeneration (13 - 32\%) are some of the most commonly 
Weight training injuries

reported injuries in powerlifting, bodybuilding and Highland Games [21, 32]. A review by Kujala et al. [49] also supports this view, whereby power athletes (defined as weightlifters, wrestlers, boxers and track and field sprinters, jumpers and throwers) had a risk ratio (RR) of 2.68 for developing arthritis of the hip, knee and ankle compared to sedentary controls. However, similar risks of arthritis were also found for endurance $(\mathrm{RR}=2.37)$ and team sports $(\mathrm{RR}=2.42)$ athletes. This suggests that while high level sports participation may increase the risk of arthritis in later life, the weight training sports do not impose greater risks than that found in endurance and team sports.

Currently, no injury epidemiology studies have assessed the rate of acute catastrophic incidents. Therefore, it is unclear how frequent such catastrophic incidents may be in the different weight training sports and how these might be affected by a variety of intrinsic and extrinsic factors. The case study literature does however indicate that the potential for catastrophic incident exists in the weight training sports with serious injury and even death possible [8, 9].

\subsubsection{Economic Cost}

No economic cost data appears to have been reported in any of the weight training injury epidemiology studies to date, even though there exists the potential for weight training to have economic costs related to the pain, discomfort and disability that the athletes may experience [50, 51]. Some insight into the economic cost of injuries may be obtained from outcomes including the cost of injury-related treatment during the athletes' competitive years, the duration and nature of injury-related treatment after retiring as well as the loss of school or work time associated with injury. Although the economic cost of injury in the weight training sports did not appear to be reported in any the studies eligible for inclusion in this review, the potential for weight training 
to result in residual adverse effects that may have economic costs during their competitive careers and retirement has been examined in the wider sports injury literature [49]. However, the results of a systematic review and meta-analysis suggest that participation in the weight training sports may be somewhat cost neutral or even beneficial. Specifically, Kujala et al. [49] reported that cardiovascular disease risk was reduced or similar in retired endurance $(\mathrm{RR}=0.24-0.73$ ), team $(\mathrm{RR}=0.48-0.86)$ and power sport $(\mathrm{RR}=0.49-0.94)$ athletes compared to sedentary controls. Similar results were observed for hospital utilization rates, whereby endurance, team and power sport athletes had RRs of $0.71,0.86$ and 0.95 compared to sedentary controls, respectively [49].

\subsection{What Are the Risk Factors?}

There are a variety of potential extrinsic and intrinsic risk factors that may predispose athletes to injury in the weight training sports. Identification of the relevant modifiable risk factors may therefore allow specific injury prevention programs to be tailored to these weight training sports; whereas a description of relevant non-modifiable risk factors may be useful for individuals who are considering participating in these sports.

\subsubsection{Intrinsic Factors}

Several studies of weight training athletes have examined the effect of intrinsic factors including sex [20-24], competitive standard (e.g. high level and low level) [20, 23, 25, 26], age (e.g. Open vs Masters) [20, 26] and bodyweight class (e.g. lightweight vs heavyweight) [20, 26] on the injury epidemiology of the weight training sports. In general, these intrinsic factors had relatively little effect on the injury epidemiology of the weight training sports. The exceptions to this generalisation are described below. 
Where significant sex differences were observed, these exceptions suggested that female lifters had significantly lower overall injury rates (1.3 vs 2.1 injuries per lifter per year) [21], a lower rate of recurrent injuries (173 vs 362 injuries per 1000 hours of exposure) [24], a significantly lower rate of acute injuries (50 vs 61\%) [20], a significantly higher rate of knee injuries (28 $32 \%$ vs 10 - 29\%) [21, 23] and a significantly lower rate of chest (0 vs 4\%) and thigh (0 vs 7\%) injuries [20] than their male counterparts. While the potential mechanisms contributing to the relatively small number of sex-related differences in aspects of their injury epidemiology are not well understood, female lifters' higher rate of knee injuries appears consistent with some findings for other sports and activities [52].

For the studies reporting significant differences between elite (international) and non-elite (national) lifters, elite lifters had a significantly lower rate of injuries (3.6 vs 5.8 injuries per 1000 hours) and acute injuries (50 vs 72\%) than non-elite lifters [20]. Elite lifters also had significantly less chest (0 vs $8 \%$ ) and shoulder injuries (32 vs 42\%) but significantly more thigh injuries (10 vs 0\%) than non-elite lifters [20].

For studies comparing the effect of age and bodyweight class, a significantly greater rate of competition injuries per athlete per year were reported among younger ( $\leq 30$ years) compared to older (> 30 years) strongman athletes (0.5 vs 0.3 injuries per year); as well as in heavyweight (>105 kg) than lightweight competitors ( $\leq 105 \mathrm{~kg})$ (0.5 vs 0.3 injuries per year) [26]. Some significant age- and bodyweight class-related differences were also observed for the severity of strongman injury [26]. Interestingly, despite the heavier loads that these athletes train and compete with, the $>105 \mathrm{~kg}$ strongman athletes had proportionally less severe (18 vs 26\%) and 
Weight training injuries

moderate injuries (47 vs 53\%) than the $\leq 105 \mathrm{~kg}$ athletes. Older strongman athletes (>30-years old) also experienced almost twice as many severe injuries (26 vs 15\%) as the $\leq 30$ year group.

While based on a limited number of peer reviewed studies, it appears that the intrinsic factors of sex, competitive standard and age and bodyweight class may have only have a relatively minor influence on the injury epidemiology of the weight training sports. This suggests that athletes of both sexes as well as a variety of competitive standards, ages and bodyweight classes may participate in these activities with similar risks of injury.

\subsubsection{Extrinsic Factors}

Factors such as coaching, the rules of the sport as well as the training environment could be extrinsic factors related to injury in the weight training sports. However, no experimental studies have so far been conducted to examine this possibility for the weight training sports.

\subsection{What are the Inciting Events?}

Several studies included in this review have attempted to gain insight into events that may contribute to injury in weight training sports [23, 26, 37, 38]. As an example, Wang et al. [23] sought to determine the inciting events that weightlifters thought contributed to injury. Weightlifters felt that $60 \%$ of their injuries were associated with tiredness (fatigue), $31 \%$ with technical errors and 21\% with excessive overload. The bodybuilders in the study by Xiaojun and colleagues [37] felt that 21\% of their injuries were caused by fatigue (and poor recovery), 18\% by training with overly heavy loads and $14 \%$ by insufficient preparation (i.e. warm up). Bodybuilders in the Eberhardt et al. [38] study felt that their injuries were a result of improper warm-up (42\%), too vigorous exercising (35\%) or by lack of “guarding assistance”, better 
Weight training injuries

known as appropriate spotting by training partners (7\%). Strongman athletes cited poor technique as the most frequent contributing factor to injury (25\%), with a wide variety of other minor inciting events influencing injury as well [26].

Unfortunately, the validity of the relatively limited inciting event data for the weight training sports appears questionable for several reasons. These include: 1) the retrospective design of the studies; 2) the relative lack of clear definitions within and between studies for an inciting event; and 3) the self-report nature of this data. Notwithstanding these limitations, fatigue has previously been implicated as an inciting factor to sporting injury $[47,48]$. Lifters may therefore need to perform the most demanding, challenging and high-risk exercises during the initial part of their training sessions to help minimize their risk of injury.

Nine studies have also sought to examine the inciting factors to injury by determining which exercises/events/disciplines are most associated with injury [20, 25, 26, 30-32, 34, 35, 38] (see Table 8). Keogh et al. [20] and Siewe et al. [30] reported that the squat, deadlift and bench press were the most common injury-causing exercises for powerlifters (31 - 61\%). Kulund et al. [35] found that the clean and jerk, squat and the snatch were the three most commonly cited injurycausing exercises for weightlifters (21 - 46\%). In contrast, the squat (11 - 24\%), bench press (6 16\%) and shoulder press (9 - 14\%) were the most common injury-causing exercises for bodybuilders [31, 38] and strongman athletes [26]. For CrossFit athletes, powerlifting, gymnastics and Olympic lifting exercises (23, 20 and 17\%, respectively) were most commonly cited as causing injury [34]. McLennan et al. [32] observed that the weight toss, caber toss and hammer throw (31, 25 and 20\%, respectively) accounted for most Highland Games event injuries, with no data available on the injuries attributable to the weight training. 
PLEASE INSERT TABLE 8 about here

The results of these studies into the inciting events for the weight training sports are of some interest but only go so far into describing the factors contributing to injury in these sports. The reason for this is that the most common inciting event exercises were typically the competitive events in the sports (i.e. powerlifting, weightlifting and Highland Games). As such, these exercises were likely to be performed more frequently in training and competition than other exercises and hence be more highly associated with injury. This relationship between exercise frequency (exposure) and injury risk was also observed among strongman competitors. Specifically, strongman athletes reported that the six most commonly performed exercises (farmer's walk, log press, stones, tire flip, axle clean and press and yoke walk) [41] accounted for $77 \%$ of all injuries reported by strongman athletes during event specific strongman training [26]. Future studies will need to calculate the relative exposure of the most common exercises to better identify which exercises may be inherently more risky than others.

\subsection{Conclusion}

Results of the 20 studies included in this systematic review suggest that most of the weight training sports have injury rates of $~ 1-2$ injuries per athlete per year and 2-4 injuries per 1000 hours of training/competition exposure. The majority of injuries reported in these studies were of minor or moderate severity and affected the shoulder, lower back and knee. While the injury epidemiology was relatively similar across the six weight training sports, Highland Games (7.5 injuries per 1000 hours) and strongman (5.5 injuries per 1000 hours) appeared to have higher rates of injury than the other four sports. While many between-sport similarities in injury 
epidemiology were observed, each of the weight training sports tended to have some subtle differences in the proportional injury rates across the various anatomical locations as well as the onset and severity of injury. Additional research is required to substantiate the magnitude of these between-sport comparisons, particularly in strongman and Highland Games, each of which had only one injury epidemiology study included in this review. While it is acknowledged that the 20 studies included in this systematic review is very small compared to samples for other sporting activities, the injury rate of the weight training sports appears considerably smaller than many other commonly performed sports. For example, recent studies on soccer, rugby union and cricket have reported 15-81 injuries per 1000 hours [53-55]. Such comparisons suggest that participation in the weight training sports results in fewer injuries than many other popular team sports.

As the weight training sports are performed by a wide variety of people differing in their age, sex, competitive standard and bodyweight class, additional research should also focus on direct comparisons between these sub-groups of weight training athletes. Further cohort studies also need to be conducted to determine how other intrinsic factors e.g. anthropometric profile, flexibility and muscular strength/endurance imbalances [56-59], extrinsic factors e.g. use of weight belts [60, 61] and inciting events e.g. fatigue, exercise technique and selection [62-64] may modulate the injury risk. Such studies will inform the development of research-based injury prevention programs which can then be tested for their efficacy in randomized controlled trials, similar to that done for sports such as soccer and handball [65].

Considerable improvements in the standard of injury epidemiology research for the weight training sports are also required. Currently, many of the studies included in this review only 
reported data for a subset of the variables recommended by the IOC for a full understanding of the epidemiology of sporting injury [11]. In particular, environmental location, onset, chronometry, clinical outcome and economic cost were infrequently (if at all) reported in the eligible studies. Greater detail on the training performed by each athlete (e.g. training frequency, number of set and repetitions, exercise performed and loads used etc.) for each weeks training would also be most useful. Such data (if involving a large enough sample of randomly selected athletes over a sufficient period of time) may allow some insight into how alterations in the training program may influence the rate of injury in these sports. A reduction in the risk of bias should also be a focus of future research, with current studies primarily limited by their study design, participant inclusion, duration of data collection, confirmation of injury diagnosis and changes in risk exposure. It is recommended that future studies utilize prospective research designs, with the participants followed for a minimum of six months. The generalizability of results would be improved if the invited participants were randomly selected from the available populations. It would also be useful to confirm injury diagnosis via medical examination. While a medical examination may be difficult to include in the retrospective designs commonly used in the literature, future prospective studies could more easily utilize a medical examination to increase the validity of the data especially for injury type [66]. This type of research may be most easily conducted at institutes of sport and national and Olympic training centres as done by Calhoon et al. [27] and Kim and Kim [24] or at specific competitions such as Olympic Games $[22,28]$.

In conclusion, the weight training sports appeared to have relatively similar injury epidemiology characteristics regardless of the age, sex, bodyweight class or competitive standard of the athlete. The injury rates for the weight training sports appeared considerably lower than that reported for 
Weight training injuries

many team sports. However, the risk of bias assessment performed in this review suggests greater methodological rigor is required in future weight training sport injury epidemiology studies to confirm the relative safety of the weight training sports.

\section{Compliance with Ethical Standards}

\section{Funding}

No sources of funding were used to assist in the preparation of this article.

\section{Conflicts of Interest}

Justin Keogh and Paul Winwood declare that they have no conflicts of interest relevant to the content of this review.

\section{Acknowledgements}

The authors would like to thank Meng-Xiao Michelle Miao and Petra Pühringer for their expertise in translating the text of the studies written in Chinese and German, respectively. 
Weight training injuries

\section{References}

1. Cholewicki J, McGill SM, Norman RW. Lumbar spine loads during the lifting of extremely heavy weights. Med Sci Sports Exerc. 1991;23(10):1179-86.

2. Escamilla RF, Fleisig GS, Lowry TM, et al. A three-dimensional biomechanical analysis of the squat during varying stance widths. Med Sci Sports Exerc. 2001;33(6):984-98.

3. Escamilla RF, Fleisig GS, Zheng N, et al. Biomechanics of the knee during closed kinetic chain and open kinetic chain exercises. Med Sci Sports Exerc. 1998;30(4):556-69.

4. Escamilla RF, Francisco A, Fleisig GS, et al. A three-dimensional biomechanical analysis of sumo and conventional style deadlifts. Med Sci Sports Exerc. 2000;32(7):1265-75.

5. McGill SM, McDermott A, Fenwick CMJ. Comparison of different strongman events: Trunk muscle activation and lumbar spine motion, load, and stiffness. J Strength Cond Res. 2009;23(4):1148-61.

6. Gill IP, Mbubaegbu C. Fracture shaft of clavicle, an indirect injury from bench pressing. Br J Sports Med. 2004;38(5):E26.

7. George SM. Simultaneous acute rotator cuff tear and distal biceps rupture in a strongman competitor. Orthop 2010;16:268-70.

8. George DH, Stakiw K, Wright CJ. Fatal accident with weight-lifting equipment: implications for safety standards. Can Med Assoc J. 1989;140(8):925-6.

9. Luke JL, Farb A, Virmani R, et al. Sudden cardiac death during exercise in a weight lifter using anabolic androgenic steroids: pathological and toxicological findings. J Forensic Sci. 1990;35(6):1441-7.

10. National Center for Catastrophic Sport Injury Research. 2016. Definition. In: Catastrophic injury. http://nccsir.unc.edu/definition-of-injury/ Accessed 13 May 2016.

11. Caine D, Harmer P, Schiff M. Preface. In: Caine D, Harmer P, Schiff M, editors. The encyclopaedia of sports medicine: The epidemiology of injury in Olympic sports. Oxford, England: Blackwell; 2009. pp. xi-xiii.

12. Keogh JWL. Weightlifting. In: Caine D, Harmer P, Schiff M, editors. The encyclopaedia of sports medicine: The epidemiology of injury in Olympic sports. Oxford, England: Blackwell; 2009. pp. 336-50.

13. Brown E, W, Kimball R, G. Medical history associated with adolescent powerlifting. Pediatrics. 1983;72(5):636-44. 
14. Malina RM. Weight training in youth-growth, maturation, and safety: an evidence-based review. Clin J Sport Med. 2006;16(6):478-87.

15. Faigenbaum AD, Kraemer WJ, Blimkie CJR, et al. Youth resistance training: updated position statement paper from the national strength and conditioning association. J Strength Cond Res. 2009;23(S5):S60-79.

16. Lloyd RS, Faigenbaum AD, Stone MH, et al. Position statement on youth resistance training: the 2014 International Consensus. Br J Sports Med. 2014;48(7):498-505. doi:10.1136/bjsports2013-092952.

17. Lopes AD, Hespanhol LCJ, Yeung SS, et al. What are the main running-related musculoskeletal injuries? A systematic review. Sports Med. 2012;42(10):891-905.

18. Kluitenberg B, van Middelkoop M, Diercks R, et al. What are the differences in injury proportions between different populations of runners? A systematic review and meta-analysis. Sports Med. 2015;45(8):1143-61.

19. Nauta J, Martin-Diener E, Martin BW, et al. Injury risk during different physical activity behaviours in children: a systematic review with bias assessment. Sports Med. 2014;45(3):32736. doi:10.1007/s40279-014-0289-0.

20. Keogh J, Hume PA, Pearson S. Retrospective injury epidemiology of one hundred one Oceania competitive power lifters: The effects of age, body mass, competitive standard, and gender. J Strength Cond Res. 2006;20(3):672-81.

21. Goertzen M, Schoppe K, Lange G, et al. Injuries and damage caused by excess stress in body building and power lifting. Sportverletz Sportsc. 1989;3(1):32-6.

22. Engebretsen L, Soligard T, Steffen K, et al. Sports injuries and illnesses during the London Summer Olympic Games 2012. Br J Sports Med. 2013;47:407-14.

23. Wang WY, Shi HF, Zuo H, et al. An epidemiological survey and comparative study of the injuries in weightlifting. Sports Sci. 2000(4):44-6.

24. Kim EK, Kim TG. Analysis of sports injuries among Korean national players during official training. J Korean Data Infor Sci Soc 2014;25(3):555-65.

25. Raske A, Norlin R. Injury incidence and prevalence among elite weight and power lifters. Am J Sports Med. 2002;30(2):248-56.

26. Winwood PW, Hume PA, Cronin JB, et al. Retrospective injury epidemiology of strongman athletes. J Strength Cond Res. 2014;28(1):28-42. 
27. Calhoon G, Fry AC. Injury rates and profiles of elite competitive weightlifters. J Athl Train. 1999;34(3):232-8.

28. Junge A, Engebretsen L, Mountjoy ML, et al. Sports injuries during the Summer Olympic Games 2008. Am J Sports Med. 2009;37(11):2165-72.

29. Haykowsky MJ, Warburton DER, Quinney HA. Pain and injury associated with powerlifting training in visually impaired athletes. J Vis Impair Blind. 1999;93:236-41.

30. Siewe J, Rudat J, Rollinghoff M, et al. Injuries and overuse syndromes in powerlifting. Int $\mathrm{J}$ Sports Med. 2011;32:703-11.

31. Siewe J, Marx G, Knoll P, et al. Injuries and overuse syndromes in competitive and elite bodybuilding. Int J Sports Med. 2014;35(11):943-8.

32. McLennan JG, McLennan JE. Injury patterns in Scottish heavy athletics. Am J Sports Med. 1990;18(5):529-32.

33. Hak PT, Hodzovic E, Hickey B. The nature and prevalence of injury during CrossFit training. J Strength Cond Res. In press.

34. Weisenthal BM, Beck CA, Maloney MD, et al. Injury rate and patterns among CrossFit athletes. Orthop J Sports Med. 2014;2(4).

35. Kulund DM, Dewey JB, Brubaker CE, et al. Olympic weight-lifting injuries. Phys Sportsmed. 1978;6:111-8.

36. Konig M, Biener K. Sport-specific injuries in weight lifting. Schweiz Z Sportmed. 1990;38(1):25-30.

37. Xiaojun Z, Taotao LI. Sport injury law and preventing methods of Chinese elite bodybuilding players. J Shenyang Inst Phys Educ. 2008;27(4):75-7.

38. Eberhardt A, Dzbański P, Fabirkiewicz K, et al. Frequency of injuries in recreational bodybuilding. Phys Educ Sport. 2007;51:40-4.

39. Kolber MJ, Beekhuizen KS, Cheng MS, et al. Shoulder injuries attributed to resistance training: a brief review. J Strength Cond Res. 2010;24(6):1696-704.

40. Neviaser TJ. Weight lifting: risks and injuries to the shoulder. Clin Sports Med. 1991;10(3):615-21.

41. Winwood PW, Keogh JWL, Harris NK. The strength and conditioning practices of strongman competitors. J Strength Cond Res. 2011;25(11):3118-28.

42. Fleck SJ, Kraemer WJ. Designing resistance training programs. 2nd ed. Champaign, IL: Human Kinetics; 1997. 
43. Kraemer WJ, Koziris LP. Olympic weightlifting and powerlifting. In: Lamb DR, Knuttgen HG, Murray R, editors. Physiology and nutrition for competitive sport. Carmel: Cooper; 1994. pp. 1-54.

44. Swinton PA, Lloyd R, Agouris I, et al. Contemporary training practices in elite British powerlifters: Survey results from an international competition. J Strength Cond Res. 2009;23(2):380-4.

45. Stone MH, Pierce KC, Sands WA, et al. Weightlifting: program design. Strength Cond J. 2006;28(2):10-7.

46. Wretenberg P, Feng Y, Arborelius UP. High- and low-bar squatting techniques during weight-training. Med Sci Sports Exerc. 1996;28(2):218-24.

47. Gabbett TJ, Domrow N. Relationships between training load, injury, and fitness in sub-elite collision sport athletes. J Sports Sci. 2007;25(13):1507-19.

48. Hawkins RD, Fuller CW. A prospective epidemiological study of injuries in four English professional football clubs. Br J Sports Med. 1999;33(3):196-203.

49. Kujala UM, Marti P, Kaprio J, et al. Occurrence of chronic disease in former top-level athletes. Predominance of benefits, risks or selection effects? Sports Med. 2003;33(8):553-61.

50. Granhed H, Morelli B. Low back pain among retired wrestlers and heavyweight lifters. Am J Sports Med. 1988;16(5):530-3.

51. Mundt DJ, Kelsey JL, Golden AL, et al. An epidemiologic study of sports and weight lifting as possible risk factors for herniated lumbar and cervical discs. Am J Sports Med. 1993;21(6):854-60.

52. Hughes G, Watkins J. A risk-factor model for anterior cruciate ligament injury. Sports Med. 2006;36(5):411-28.

53. Clausen MB, Zebis MK, Moller M, et al. High injury incidence in adolescent female soccer. Am J Sports Med. 2014;42(10):2487-94. doi:10.1177/0363546514541224.

54. Williams S, Trewartha G, Kemp S, et al. A meta-analysis of injuries in senior men's professional rugby union. Sports Med. 2013;43(10):1043-55. doi:10.1007/s40279-013-0078-1.

55. Orchard J, James T, Kountouris A, et al. Changes to injury profile (and recommended cricket injury definitions) based on the increased frequency of Twenty20 cricket matches. Open Access J Sports Med. 2010;1:63-76.

56. Barlow JC, Benjamin BW, Birt PJ, et al. Shoulder strength and range-of-motion characteristics in bodybuilders. J Strength Cond Res. 2002;16(3):367-72. 
57. Gross ML, Brenner SL, Esformes I, et al. Anterior shoulder instability in weight lifters. Am J Sports Med. 1993;21(4):599-603. doi:10.1177/036354659302100419.

58. Keogh JWL, Hume PA, Pearson SN, et al. Can absolute and proportional anthropometric characteristics distinguish stronger and weaker powerlifters? J Strength Cond Res. 2009;23(8):2256-65.

59. Keogh JWL, Hume PA, Pearson SN, et al. Anthropometric dimensions of male powerlifters of varying body mass. J Sport Sci. 2007;25(2):1365-76

60. Kraus JF, Schaffer KB, Rice T, et al. A field trial of back belts to reduce the incidence of acute low back injuries in New York City home attendants. Int J Occup Med Environ Health. 2002;8(2):97-104.

61. Reddell CR, Congleton JJ, Huchingson DR, et al. An evaluation of a weightlifting belt and back injury prevention training class for airline baggage handlers. Appl Ergon. 1992;23(5):31929.

62. Fees M, Decker T, Snyder-Mackler L, et al. Upper extremity weight-training modifications for the injured athlete. A clinical perspective. Am J Sports Med. 1998;26(5):732-42.

63. McGill SM. Ultimate back fitness and performance. Waterloo, Ont: Wabuno Publishers; 2004.

64. Gabbett TJ. Incidence, site, and nature of injuries in amateur rugby league over three consecutive seasons. Br J Sports Med. 2000;34(2):98-103. doi:10.1136/bjsm.34.2.98.

65. Parkkari J, Kujala UM, Kannus P. Is it possible to prevent sports injuries? Review of controlled clinical trials and recommendations for future work. Sports Med. 2001;31(14):985-95. 66. Gabbe BJ, Finch CF, Bennell KL, et al. How valid is a self reported 12 month sports injury history? Br J Sports Med. 2003;37:545-7. 
Weight training injuries

Table 1. Risk of bias assessment of the studies

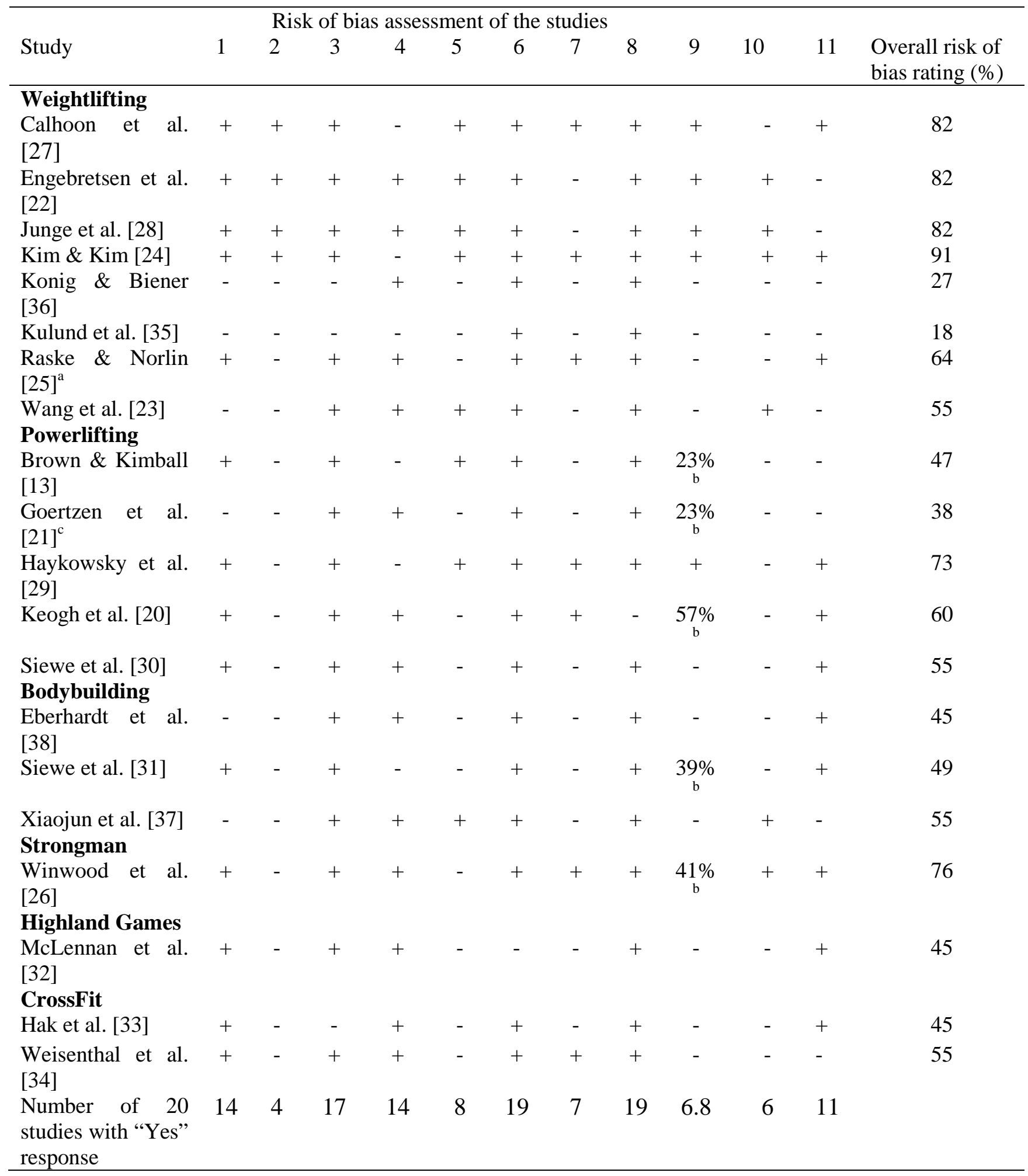


Method for assessing risk of bias. (1) Definition of injury clearly described. (2) A prospective design was used. (3) Clear description of the subject demographics within the study is given. (4) Subject sample size is $\geq 100$ (5) The process of inclusion of participants was at random or the data collection was performed with the entire target population. (6) Data analysis was conducted in at least $80 \%$ of the included subjects. (7) Data collection was appropriate. For prospective studies at least a 6-month follow up, for retrospective studies up to a 12 month recall period (8) Same mode of data collection (e-mail, telephone, interview, etc.) was used. (9) The injury diagnosis was conducted by health professionals. (10) Changes in risk exposure were taken into account (i.e. seasonal changes, periodized block, training versus competition). (11) Number of injuries reported by exposure time to weight training. Note: If there was insufficient information in the article to permit a judgment for a particular criterion, the answer was "No: high risk of bias" for that particular criterion. \% Indicates \% of injuries diagnosed by medical professional; + indicates yes: low risk of bias; - indicates no: high risk of bias.

a Study includes powerlifting and weightlifting athletes. b Percentage of subjects that reported the injury was medically diagnosed. c Study includes powerlifting and bodybuilding athletes. 
Weight training injuries

Table 2. Summary of studies injury/pain definition

\begin{tabular}{ll}
\hline Study & \multicolumn{1}{c}{ Injury/Pain definition } \\
\hline $\begin{array}{l}\text { Weightlifting } \\
\text { Calhoon et al. }\end{array}$ \\
$\begin{array}{l}\text { Injuries were defined by classifications: } \\
\text { Acute injuries are "injuries with rapid onset due to traumatic episode, but } \\
\text { with short duration”. A chronic injury is "an injury with long onset and } \\
\text { duration". A recurring injury involves recovery and re-injury for a particular } \\
\text { condition." }\end{array}$
\end{tabular}

Engebretsen et Injury was defined as a "new or recurring musculoskeletal complaints or al. [22] concussions or illnesses incurred during competition or training during the London Olympic Games (27 July-12 August 2012) receiving medical attention, regardless of the consequences with respect to absence from competition or training."

Junge et al. [28] An injury was defined as "any musculoskeletal complaint (traumatic and overuse) newly incurred due to competition and/or training during the XXIXth Olympiad in Beijing that received medical attention regardless of the consequences with respect to absence from competition or training.”

Kim \& Kim An injury was defined as "any musculoskeletal symptoms and signs that [24] required medical attention.”

Konig \& Biener No formal definition of injury provided.

[36]

Kulund et al. No formal definition of injury provided.

[35]

Wang et al. [23] No formal definition of injury provided.

Powerlifting

Brown

Kimball [13]

\& Subjects responded to questionnaire items on types and sites of injuries that were severe enough to cause them to discontinue training for at least one day.

Goertzen et al. No formal definition of injury provided.

$[21]^{\mathrm{a}}$

Haykowsky et Injury was defined as "the number and severity of powerlifting-related al. [29] injuries that required medical intervention (from a physician, chiropractor, or physical therapist) and that resulted in an interruption in training for more than one day within the last year was assessed.”.

Keogh et al. Injury was defined as "any physical damage to the body that caused the lifter [20] to miss or modify one or more training sessions or miss a competition.”

Raske \& Norlin The definition of injury was "an inability to train or compete as planned.” $[25]^{\mathrm{b}}$

Siewe et al. [30] Injury was defined as "an incident leading to an interruption in training or 


\section{Bodybuilding}

competition.”

Eberhardt et al. No formal definition of injury provided.

[38]

Siewe et al. [31] Injury was defined as "an incident provoking an interruption in either training or competition.”

Xiaojun et al. No formal definition of injury provided.

[37]

\section{Strongman}

Winwood et al. Injury was defined as "any physical damage to the body that caused the [26]

\section{Highland}

Games

McLennan et al. Injury was defined as "a mishap occurring during meets or training that resulted in the inability to compete or practice normally.”

\section{Crossfit}

Hak et al. [33] strongman athlete to miss or modify one or more training sessions or miss a competition.”

$$
\text { resulted in the inability to compete or practice normally." }
$$

Injury was defined as "any injury sustained during training which prevented the participant training, working or competing in any way and for any period of time.”

Weisenthal et al. "'Injury”' encompassed any new musculoskeletal pain, feeling, or injury that [34] results from a CrossFit workout and leads to 1 or more of the following options:

1) Total removal from CrossFit training and other outside routine physical activities for $>1$ week; 2) Modification of normal training activities in duration, intensity, or mode for $>2$ weeks; and 3) Any physical complaint severe enough to warrant a visit to a health professional.

a Study includes powerlifting and bodybuilding athletes. b Study includes powerlifting and weightlifting athletes. 
Table 3. Summary of the incidence \& frequency of weight training injuries.

\begin{tabular}{|c|c|c|c|c|c|c|c|c|}
\hline Study & Athletes & Study design & $\begin{array}{c}\text { Study } \\
\text { duration }\end{array}$ & $\begin{array}{l}\text { Number } \\
\text { of } \\
\text { injuries }\end{array}$ & $\begin{array}{c}\text { Clinical } \\
\text { incidence } \\
\text { (injuries/ } \\
\text { lifter/y) }\end{array}$ & $\begin{array}{c}\text { Injury } \\
\text { incidence/rate } \\
\text { (injuries/1000 } \\
\text { hr) }\end{array}$ & $\begin{array}{c}\text { Sport } \\
\text { injuries/1000 } \\
\text { athlete } \\
\text { exposures } \\
\text { (1000 AE's) }\end{array}$ & $\begin{array}{l}\text { Athlete rate } \\
\text { (\% injured) }\end{array}$ \\
\hline \multicolumn{9}{|l|}{ Weightlifting } \\
\hline $\begin{array}{l}\text { Calhoon et al. } \\
\text { [27] }\end{array}$ & Open elite (NS) & Prospective & $72 \mathrm{mo}$ & 560 & & $3.3^{\mathrm{a}}$ & & \\
\hline $\begin{array}{l}\text { Engebretsen et } \\
\text { al. [22] }\end{array}$ & $\begin{array}{l}149 \text { M \& } 103 \text { F } \\
\text { open elite }\end{array}$ & Prospective & 17 days $^{\mathrm{b}}$ & 44 & & & & $18^{\mathrm{C}}$ \\
\hline $\begin{array}{l}\text { Engebretsen et } \\
\text { al. [22] }\end{array}$ & $\begin{array}{l}149 \mathrm{M} \text { open } \\
\text { elite }\end{array}$ & Prospective & 17 days $^{b}$ & 27 & & & & $18^{\mathrm{C}}$ \\
\hline $\begin{array}{l}\text { Engebretsen et } \\
\text { al. [22] }\end{array}$ & $103 \mathrm{~F}$ open elite & Prospective & 17 days $^{\mathrm{b}}$ & 16 & & & & $16^{\mathrm{c}}$ \\
\hline Junge et al. [28] & $\begin{array}{l}255 \text { elite } \mathrm{M} \& \\
\mathrm{~F}\end{array}$ & Prospective & 16 days $^{\mathrm{b}}$ & 43 & & & & $17^{\mathrm{C}}$ \\
\hline Kim \& Kim [24] & $\begin{array}{l}\text { National } \quad M \\
\text { (NS) }\end{array}$ & Prospective & 271 days & 125 & & & $100 \& 362^{\mathrm{d}}$ & \\
\hline Kim \& Kim [24] & National F (NS) & Prospective & 271 days & 82 & & & $129 \& 173^{\mathrm{d}}$ & \\
\hline $\begin{array}{l}\text { Konig \& Biener } \\
\text { [36] }\end{array}$ & $121 \mathrm{M}$ & Retro quest & $\mathrm{EC}$ & 202 & $1.7^{\mathrm{e}}$ & & & \\
\hline $\begin{array}{l}\text { Kulund et al. } \\
\text { [35] }\end{array}$ & $80 \mathrm{M}$ & Retro quest & NS & 111 & $1.4^{\mathrm{e}}$ & & & \\
\hline $\begin{array}{l}\text { Raske \& Norlin } \\
{[25]^{\mathrm{f}}}\end{array}$ & 50 open elite $\mathrm{M}$ & Retro quest & $24 \mathrm{mo}$ & 108 & 1.1 & 2.4 & & \\
\hline $\begin{array}{l}\text { Raske \& Norlin } \\
{[25]^{\mathrm{g}}}\end{array}$ & $\begin{array}{l}50 \text { open non- } \\
\text { elite } \mathrm{M}\end{array}$ & Retro quest & $24 \mathrm{mo}$ & 98 & 1.0 & 2.9 & & \\
\hline Wang et al. [23] & 195 open M & Retro quest & NS & NS & & & & 74 \\
\hline Wang et al. [23] & 70 open $F$ & Retro quest & NS & NS & & & & 90 \\
\hline \multicolumn{9}{|l|}{ Powerlifting } \\
\hline $\begin{array}{l}\text { Brown \& } \\
\text { Kimball [13] }\end{array}$ & $\begin{array}{l}71 \text { junior } \\
\text { novice } M\end{array}$ & Retro quest & $17 \mathrm{mo}$ & 98 & 1.0 & 2.8 & & \\
\hline
\end{tabular}


Weight training injuries

\begin{tabular}{|c|c|c|c|c|c|c|}
\hline $\begin{array}{l}\text { Goertzen et al. } \\
\text { [21] }\end{array}$ & 39 open $\mathrm{M}$ & $\begin{array}{l}\text { Retro quest \& } \\
\text { orthopedic } \\
\text { exam }\end{array}$ & $18 \mathrm{mo}$ & 120 & 2.1 & \\
\hline $\begin{array}{l}\text { Goertzen et al. } \\
\text { [21] }\end{array}$ & 21 open $F$ & $\begin{array}{l}\text { Retro quest \& } \\
\text { orthopedic } \\
\text { exam }\end{array}$ & $18 \mathrm{mo}$ & 40 & 1.3 & \\
\hline $\begin{array}{l}\text { Haykowsky et al. } \\
\text { [29] }\end{array}$ & $\begin{array}{l}9 \text { M \& } 2 \text { F open } \\
\text { elite blind }\end{array}$ & Retro quest & $12 \mathrm{mo}$ & 4 & 0.4 & 1.1 \\
\hline Keogh et al. [20] & $82 \mathrm{M} \& 19 \mathrm{~F}$ & Retro quest & $12 \mathrm{mo}$ & 118 & 1.2 & 4.4 \\
\hline Keogh et al. [20] & $82 \mathrm{M}$ & Retro quest & $12 \mathrm{mo}$ & 98 & 1.2 & 4.7 \\
\hline Keogh et al. [20] & $19 \mathrm{~F}$ & Retro quest & $12 \mathrm{mo}$ & 20 & 1.1 & 3.1 \\
\hline Keogh et al. [20] & 36 national & Retro quest & $12 \mathrm{mo}$ & 50 & 1.4 & 5.8 \\
\hline Keogh et al. [20] & 65 international & Retro quest & $12 \mathrm{mo}$ & 68 & 1.0 & 3.6 \\
\hline Keogh et al. [20] & 59 lightweight & Retro quest & $12 \mathrm{mo}$ & 62 & 1.1 & 4.3 \\
\hline Keogh et al. [20] & 42 heavyweight & Retro quest & $12 \mathrm{mo}$ & 56 & 1.3 & 4.4 \\
\hline Keogh et al. [20] & 59 open & Retro quest & $12 \mathrm{mo}$ & 62 & 1.1 & 4.0 \\
\hline Keogh et al. [20] & 42 masters & Retro quest & $12 \mathrm{mo}$ & 56 & 1.3 & 4.7 \\
\hline $\begin{array}{l}\text { Raske \& Norlin } \\
{ }_{[25]^{f}}\end{array}$ & $\begin{array}{l}50 \text { Open elite } \\
\text { M }\end{array}$ & Retro quest & $24 \mathrm{mo}$ & 114 & 1.1 & 2.7 \\
\hline $\begin{array}{l}\text { Siewe et al. } \\
\text { [30] }\end{array}$ & $\begin{array}{l}219 \text { M \& } 26 \text { F } \\
\text { open \& elite }\end{array}$ & Retro quest & $\mathrm{EC}$ & NS & 0.3 & 1.0 \\
\hline \multicolumn{7}{|l|}{ Bodybuilding } \\
\hline $\begin{array}{l}\text { Eberhardt et al. } \\
\text { [38] }\end{array}$ & 250 open M & Retro quest & $46 \mathrm{mo}$ & 311 & 0.4 & 1.0 \\
\hline $\begin{array}{l}\text { Goertzen et al. } \\
\text { [21] }\end{array}$ & 240 open M & $\begin{array}{l}\text { Retro quest \& } \\
\text { orthopedic } \\
\text { exam }\end{array}$ & $18 \mathrm{mo}$ & 235 & 0.7 & \\
\hline $\begin{array}{l}\text { Goertzen et al. } \\
\text { [21] }\end{array}$ & 118 open F & $\begin{array}{l}\text { Retro quest \& } \\
\text { orthopedic } \\
\text { exam }\end{array}$ & $18 \mathrm{mo}$ & 53 & 0.3 & \\
\hline Siewe et al. [31] & $\begin{array}{l}54 \text { M \& } 17 \text { F } \\
\text { open \& elite }\end{array}$ & Retro quest & EC & NS & 0.12 & $0.24^{\mathrm{h}}$ \\
\hline Xiaojun et al. & 104 elite & Retro quest & $12 \mathrm{mo}$ & 180 & 1.8 & \\
\hline
\end{tabular}




\section{[37] $74 \mathrm{M} \& 30 \mathrm{~F}$}

\section{Strongman}

Winwood et al.

[26]

213 low \& high Retro quest level $\mathrm{M}$

Winwood et al.

[26]

92 low level

82 high level

Retro quest

Retro quest

Retro quest

Retro quest

$100>105 \mathrm{~kg}$

[26]

$91 \leq 30 \mathrm{y}$

Retro quest

Winwood et al.

$82>30 \mathrm{y}$

Retro quest

$\begin{array}{llll}12 \mathrm{mo} & 257 & 1.6 \& 0.4^{\mathrm{i}} & 5.5 \\ & & & \\ 12 \mathrm{mo} & \mathrm{NS} & 1.4 \& 0.3^{\mathrm{i}} & 5.4 \\ 12 \mathrm{mo} & \mathrm{NS} & 1.5 \& 0.5^{\mathrm{i}} & 4.9 \\ 12 \mathrm{mo} & \mathrm{NS} & 1.6 \& 0.3^{\mathrm{i}} & 6.1 \\ 12 \mathrm{mo} & \mathrm{NS} & 1.6 \& 0.5^{\mathrm{i}} & 4.5 \\ 12 \mathrm{mo} & \mathrm{NS} & 1.6 \& 0.5^{\mathrm{i}} & 5.5 \\ 12 \mathrm{mo} & \text { NS } & 1.5 \& 0.3^{\mathrm{i}} & 5.4\end{array}$

\section{Highland}

\section{Games}

McLennan et al.

[32]

\section{CrossFit}

Hak et al.

[33] amateur

Weisenthal et al.

93 M \& 39 F Retro quest
open

EC

186 open

[34] open

NS Not stated. EC Study duration was the athlete's entire career for the sport. Retro quest Retrospective questionnaire, mo Month. y Year. hr Hours. M Male, F Female. a From subset of 27 resident lifters. b Data collected during an Olympic competition (16 or 17days). c \% of athletes injured during the Olympic competition. d Acute and recurrent (respectively). e Total number of injuries per lifter over unknown duration. f Data from 2000. g Data from 1995. h Values indicate injury rate. i Values indicate training injuries and competition injuries per lifter/per year (respectively). j \% of injuries over 6 months. 
Weight training injuries

Table 4. Summary of weight training injuries by (in general) the most frequently anatomical locations.

\begin{tabular}{|c|c|c|c|c|c|c|c|c|}
\hline \multirow[t]{2}{*}{ Study } & \multirow[t]{2}{*}{ Athletes } & \multirow[t]{2}{*}{ Study design } & \multirow{2}{*}{$\begin{array}{c}\text { Number of } \\
\text { injuries }\end{array}$} & \multicolumn{5}{|c|}{ Most frequently injured anatomical locations } \\
\hline & & & & Shoulder (\%) & $\begin{array}{c}\text { Lower } \\
\text { Back (\%) }\end{array}$ & Knee (\%) & $\begin{array}{c}\text { Elbow } \\
(\%)\end{array}$ & Wrist/Hand (\%) \\
\hline \multicolumn{9}{|l|}{ Weightlifting } \\
\hline Calhoon et al. [27] & $\begin{array}{l}\text { Open elite } \\
\text { (NS) }\end{array}$ & Prospective & 560 & 18 & 23 & 19 & 3 & 10 \\
\hline Kim \& Kim [24] & $\begin{array}{c}\text { National M \& } \\
\text { F (NS) }\end{array}$ & Prospective & 207 & 7 & 8 & 10 & 4 & 21 \\
\hline $\begin{array}{l}\text { Konig \& Biener } \\
\text { [36] }\end{array}$ & $121 \mathrm{M}$ & Retro quest & 202 & $22^{\mathrm{a}}$ & 21 & 25 & 6 & 2 \\
\hline Kulund et al. [35] & $80 \mathrm{M}$ & Retro quest & 111 & 23 & 7 & 23 & 10 & 23 \\
\hline $\begin{array}{l}\text { Raske \& Norlin } \\
{[25]^{\mathrm{b}}}\end{array}$ & $\begin{array}{c}50 \text { open elite } \\
\text { M }\end{array}$ & Retro quest & 108 & 14 & 18 & 20 & 7 & 10 \\
\hline $\begin{array}{l}\text { Raske \& Norlin } \\
{[25]^{\mathrm{C}}}\end{array}$ & $\begin{array}{l}50 \text { open non- } \\
\text { elite } \mathrm{M}\end{array}$ & Retro quest & 98 & 22 & 18 & 18 & 9 & 5 \\
\hline Wang et al. [23] & 195 open M & Retro quest & NS & $15^{\mathrm{d}}$ & 19 & 29 & $9^{\mathrm{e}}$ & 20 \\
\hline Wang et al. [23] & 70 open F & Retro quest & NS & & 18 & 32 & & 17 \\
\hline \multicolumn{9}{|l|}{ Powerlifting } \\
\hline $\begin{array}{l}\text { Brown \& Kimball } \\
\text { [13] }\end{array}$ & $\begin{array}{l}71 \text { junior } \\
\text { novice } \mathrm{M}\end{array}$ & Retro quest & 98 & 6 & 50 & 8 & 6 & 4 \\
\hline Goertzen et al. [21] & 39 open $\mathrm{M}$ & $\begin{array}{l}\text { Retro quest \& } \\
\text { orthopedic } \\
\text { exam }\end{array}$ & 120 & 32 & $33^{f}$ & 10 & 13 & 6 \\
\hline Goertzen et al. [21] & 21 open $F$ & $\begin{array}{l}\text { Retro quest \& } \\
\text { orthopedic } \\
\text { exam }\end{array}$ & 40 & 22 & $24^{\mathrm{t}}$ & 28 & 10 & 10 \\
\hline $\begin{array}{l}\text { Haykowsky et al. } \\
\text { [29] }\end{array}$ & $\begin{array}{l}9 \mathrm{M} \& 2 \mathrm{~F} \\
\text { open elite }\end{array}$ & Retro quest & 4 & 25 & 25 & & 25 & \\
\hline
\end{tabular}


Weight training injuries

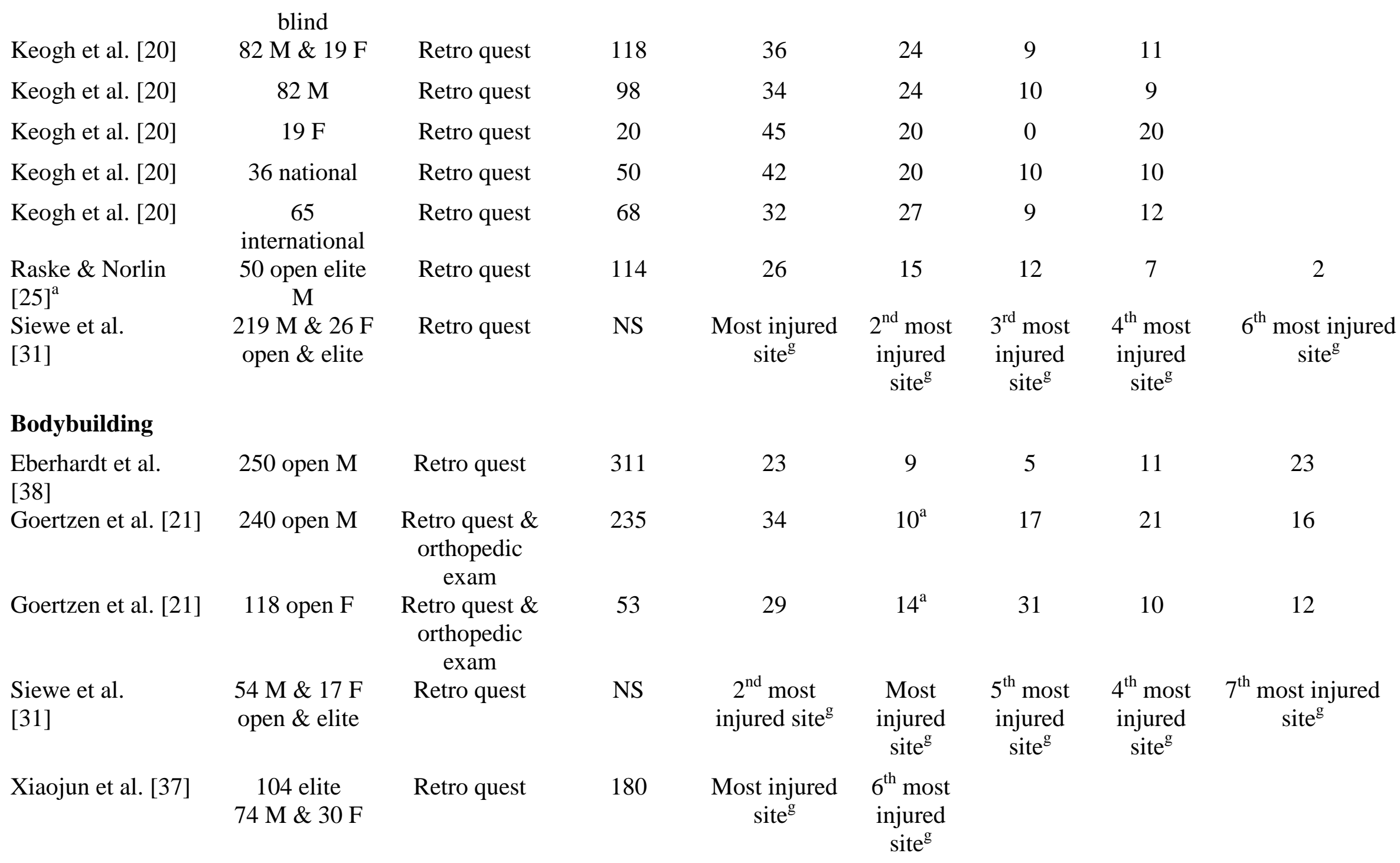

\section{Strongman}

Winwood et al. [26] 
Weight training injuries

\section{Highland Games}

McLennan

[32]

CrossFit

Hak et al.

[33]

$$
\text { et al. } 45 \text { elite }+125 \quad \text { Retro quest }
$$

729

18

$17^{\mathrm{f}}$

17

14

Weisenthal et al.

93 M \& 39 F

Retro quest

186

26

$20^{\mathrm{f}}$

10

$13^{\mathrm{f}}$

10

[34]

$$
\text { open }
$$

$$
\mathrm{F} \text { open }
$$

84

25

14

13

5

6

NS Not stated. M Male. F Female. Retro quest Retrospective questionnaire. a Shoulder girdle. b Data from 2000. c Data from 1995.

d Combined data for males and female lifters. eArm and elbow. f Entire vertebral column. g No percentage given, or percentage given based on if athlete had an injury to that site in their entire career. 
Weight training injuries

Table 5. Summary of onset of weight training injuries.

\begin{tabular}{|c|c|c|c|c|c|}
\hline \multirow[t]{2}{*}{ Study } & \multirow[t]{2}{*}{ Athletes } & \multirow[t]{2}{*}{ "Study design } & \multirow[t]{2}{*}{ Number of injuries } & \multicolumn{2}{|c|}{ Injury onset } \\
\hline & & & & Acute (\%) & Chronic (\%) \\
\hline \multicolumn{6}{|l|}{ Weightlifting } \\
\hline Calhoon et al. [27] & Open elite (NS) & Prospective & 560 & 60 & 30 \\
\hline Engebretsen et al. [22] & 149 M \& 103 F open elite & Prospective & 44 & NS & 34 \\
\hline Junge et al. [28] & 255 elite $M$ \& F & Prospective & 43 & NS & $>40$ \\
\hline Kim \& Kim [24] & National M (NS) & Prospective & 125 & 27 & NS \\
\hline Kim \& Kim [24] & National F (NS) & Prospective & 82 & 35 & NS \\
\hline Wang et al. [23] & 195 open M \& 70 open F & Retro quest & 257 & 26 & 42 \\
\hline \multicolumn{6}{|l|}{ Powerlifting } \\
\hline Keogh et al. [20] & $82 \mathrm{M} \& 19 \mathrm{~F}$ & Retro quest & 118 & 59 & 41 \\
\hline Keogh et al. [20] & $82 \mathrm{M}$ & Retro quest & 98 & 61 & 39 \\
\hline Keogh et al. [20] & $19 \mathrm{~F}$ & Retro quest & 20 & 50 & 50 \\
\hline Keogh et al. [20] & 36 national & Retro quest & 50 & 72 & 28 \\
\hline Keogh et al. [20] & 65 international & Retro quest & 68 & 50 & 50 \\
\hline Raske \& Norlin [25] & $\begin{array}{l}50 \mathrm{M} \& 10 \mathrm{~F} \text { open elite PL } \\
50 \mathrm{M} \& 5 \mathrm{~F} \text { open elite WL }\end{array}$ & Retro quest & 254 & 25 & 25 \\
\hline \multicolumn{6}{|l|}{ Strongman } \\
\hline Winwood et al. [26] & $174^{\mathrm{b}}$ low \& hih level $\mathrm{M}$ & Retro quest & 258 & 68 & 31 \\
\hline Winwood et al. [26] & $92^{\mathrm{b}}$ low level & Retro quest & 136 & 68 & 33 \\
\hline Winwood et al. [26] & $82^{\mathrm{b}}$ high level & Retro quest & 121 & 69 & 31 \\
\hline Winwood et al. [26] & $71^{\mathrm{b}} \leq 105 \mathrm{~kg}$ & Retro quest & 100 & 68 & 32 \\
\hline Winwood et al. [26] & $100^{\bar{b}}>105 \mathrm{~kg}$ & Retro quest & 154 & 68 & 32 \\
\hline Winwood et al. [26] & $91^{\mathrm{b}} \leq 30 \mathrm{y}$ & Retro quest & 128 & 65 & 35 \\
\hline Winwood et al. [26] & $82^{b}>30 y$ & Retro quest & 129 & 72 & 28 \\
\hline
\end{tabular}

NS Not stated. M male. F Female. Retro quest Retrospective questionnaire. a Data from 2000 and consisting of a mixed group of powerlifters

(PL) and weight lifters (WL). b Number of injured athletes 
Weight training injuries

Table 6. Summary of most common types of weight training injuries.

\begin{tabular}{|c|c|c|c|c|c|c|c|c|}
\hline \multirow[t]{2}{*}{ Study } & \multirow[t]{2}{*}{ Athletes } & \multirow[t]{2}{*}{ Study design } & \multirow{2}{*}{$\begin{array}{l}\text { Number of } \\
\text { injuries }\end{array}$} & \multicolumn{5}{|c|}{ Injury type } \\
\hline & & & & $\begin{array}{l}\text { Arthritis } \\
\text { (\%) }\end{array}$ & $\begin{array}{c}\text { Cartilage } \\
\text { damage/ } \\
\text { degeneration } \\
(\%)\end{array}$ & $\begin{array}{l}\text { Sprain } \\
\text { (\%) }\end{array}$ & Strain (\%) & Tendinitis (\%) \\
\hline \multicolumn{9}{|l|}{ Weightlifting } \\
\hline $\begin{array}{l}\text { Calhoon et al. } \\
\text { [27] }\end{array}$ & Open elite (NS) & Prospective & 560 & & & 13 & 45 & 24 \\
\hline $\begin{array}{l}\text { Konig \& } \\
\text { Biener [36] }\end{array}$ & $121 \mathrm{M}$ & Retro quest & 202 & & 3 & 39 & 29 & \\
\hline \multicolumn{9}{|l|}{ Powerlifting } \\
\hline $\begin{array}{l}\text { Brown \& } \\
\text { Kimball [13] }\end{array}$ & 71 junior novice $M$ & Retro quest & 98 & & & 4 & 62 & 12 \\
\hline $\begin{array}{l}\text { Goertzen et al. } \\
\text { [21] }\end{array}$ & 39 open $\mathrm{M}$ & $\begin{array}{l}\text { Retro quest \& } \\
\text { orthopedic exam }\end{array}$ & 120 & 29 & 17 & 6 & 6 & 28 \\
\hline $\begin{array}{l}\text { Goertzen et al. } \\
\text { [21] }\end{array}$ & 21 open $F$ & $\begin{array}{l}\text { Retro quest \& } \\
\text { orthopedic exam }\end{array}$ & 40 & 17 & 9 & 17 & 11 & 25 \\
\hline $\begin{array}{l}\text { Haykowsky et } \\
\text { al. [29] }\end{array}$ & $\begin{array}{l}9 \text { M \& } 2 \text { F open } \\
\text { elite blind }\end{array}$ & Retro quest & 4 & & & & $\begin{array}{l}\text { Most } \\
\text { common } \\
\text { injury } \\
\text { type }^{\mathrm{a}}\end{array}$ & \\
\hline \multicolumn{9}{|l|}{ Bodybuilding } \\
\hline $\begin{array}{l}\text { Eberhardt et al. } \\
\text { [38] }\end{array}$ & 250 open M & Retro quest & 311 & & & 39 & $10^{\mathrm{b}}$ & \\
\hline $\begin{array}{l}\text { Goertzen et al. } \\
\text { [21] }\end{array}$ & 240 open M & $\begin{array}{l}\text { Retro quest \& } \\
\text { orthopedic exam }\end{array}$ & 235 & 18 & 32 & 6 & 7 & 23 \\
\hline $\begin{array}{l}\text { Goertzen et al. } \\
\text { [21] }\end{array}$ & 118 open M & $\begin{array}{l}\text { Retro quest \& } \\
\text { orthopedic exam }\end{array}$ & 53 & 8 & 28 & 13 & 8 & 33 \\
\hline $\begin{array}{l}\text { Xiaojun et al. } \\
\text { [37] }\end{array}$ & $\begin{array}{l}104 \text { elite } \\
74 \text { M \& } 30 \text { F }\end{array}$ & Retro quest & 180 & $3^{c}$ & & 63 & 34 & \\
\hline
\end{tabular}


Weight training injuries

\section{Strongman}

Winwood et al.

[26]

Highland

Games

McLennan

$174^{\mathrm{d}}$ low $\&$ high $\quad$ Retro quest

level $\mathrm{M}$

al. [32]
174

729

3

13

4

$26^{\mathrm{g}}$

38

NS Not stated. M Male. F Female. Retro quest Retrospective questionnaire. a Percentage not stated. b Includes muscle/joint injuries. c Bone related injuries. d Number of injured athletes. e Ligament sprain/tear. f Includes tendon strains/tears. g Includes musculoligamentous injuries to the back (14\%). 
Weight training injuries

Table 7. Summary of severity/time loss of weight training injuries.

\begin{tabular}{|c|c|c|c|c|c|c|c|}
\hline \multirow[t]{2}{*}{ Study } & \multirow[t]{2}{*}{ Athletes } & \multirow{2}{*}{$\begin{array}{l}\text { Study } \\
\text { design }\end{array}$} & \multirow{2}{*}{$\begin{array}{l}\text { Number of } \\
\text { injuries }\end{array}$} & \multicolumn{4}{|c|}{ Severity/time loss } \\
\hline & & & & $\begin{array}{l}\text { Mild } \\
\text { injury } \\
(\%)\end{array}$ & $\begin{array}{l}\text { Moderate injury } \\
\text { (\%) }\end{array}$ & Major injury (\%) & $\begin{array}{c}\text { Time loss/injury } \\
(\%)\end{array}$ \\
\hline \multicolumn{8}{|l|}{ Weightlifting } \\
\hline Calhoon et al. [27] & $\begin{array}{l}\text { Open elite } \\
\text { (NS) }\end{array}$ & Prospective & & & & & $\begin{array}{l}99 \text { all injuries } \\
\leq 7 \text { day }\end{array}$ \\
\hline $\begin{array}{l}\text { Engebretsen et al. } \\
{[22]}\end{array}$ & $\begin{array}{l}149 \text { M \& } 103 \text { F } \\
\text { open elite }\end{array}$ & Prospective & 44 & & & & $\begin{array}{l}43 \geq 1 \text { day } \\
25 \geq 7 \text { days }\end{array}$ \\
\hline Junge et al. [28] & $\begin{array}{l}255 \text { open elite } \\
\text { M \& F }\end{array}$ & Prospective & 43 & & & & $\begin{array}{c}11.4 \% \text { athletes } \\
\text { with time loss } \\
\text { injuries }^{\mathrm{a}}\end{array}$ \\
\hline Konig \& Biener [36] & $121 \mathrm{M}$ & Retro quest & 202 & & & & $\begin{array}{c}82 \text { knee } \& 76 \\
\text { shoulder injuries } \\
\leq 7 \text { days }\end{array}$ \\
\hline Kulund et al. [35] & $80 \mathrm{M}$ & Retro quest & 111 & & & & $\begin{array}{l}57 \text { all injuries } \\
\leq 14 \text { days }\end{array}$ \\
\hline Wang et al. [23] & $\begin{array}{l}195 \text { open M \& } 70 \\
\text { open F }\end{array}$ & Retro quest & 257 & 45 & 55 & 1 & \\
\hline \multicolumn{8}{|l|}{ Powerlifting } \\
\hline $\begin{array}{l}\text { Brown \& Kimball } \\
\text { [13] }\end{array}$ & $\begin{array}{l}71 \text { junior novice } \\
\mathrm{M}\end{array}$ & Retro quest & 98 & & & & 12 days \\
\hline $\begin{array}{l}\text { Haykowsky et al. } \\
\text { [29] }\end{array}$ & $\begin{array}{l}9 \text { M \& } 2 \text { F open } \\
\text { elite blind }\end{array}$ & Retro quest & 4 & & & & 12 days \\
\hline Keogh et al. [20] & 82 M \& 19 F & Retro quest & 118 & 39 & 39 & 22 & \\
\hline Keogh et al. [20] & $82 \mathrm{M}$ & Retro quest & 98 & 36 & 38 & 24 & \\
\hline Keogh et al. [20] & $19 \mathrm{~F}$ & Retro quest & 20 & 50 & 40 & 10 & \\
\hline Keogh et al. [20] & 36 national & Retro quest & 50 & 40 & 42 & 18 & \\
\hline Keogh et al. [20] & 65 international & Retro quest & 68 & 38 & 37 & 25 & \\
\hline
\end{tabular}


Weight training injuries

\begin{tabular}{|c|c|c|c|c|c|c|c|}
\hline Raske \& Norlin [25] ${ }^{\mathrm{b}}$ & $\begin{array}{l}50 \mathrm{M} \& 10 \mathrm{~F} \text { open } \\
\text { elite PL } \\
50 \mathrm{M} \text { and } 5 \mathrm{~F} \text { open } \\
\text { elite WL }\end{array}$ & Retro quest & 254 & & & & $\begin{array}{c}93 \text { shoulder, } 85 \\
\text { lower back \& } 80 \\
\text { knee injuries } \\
>30 \text { days }\end{array}$ \\
\hline \multicolumn{8}{|l|}{ Bodybuilding } \\
\hline Xiaojun et al. [37] & $\begin{array}{l}104 \text { elite } \\
74 \text { M \& } 30 \text { F }\end{array}$ & Retro quest & 180 & 59 & 28 & 13 & \\
\hline \multicolumn{8}{|l|}{ Strongman } \\
\hline Winwood et al. [26] & $\begin{array}{l}174^{\mathrm{C}} \text { low \& high } \\
\text { level M }\end{array}$ & Retro quest & 261 & 33 & 47 & 20 & \\
\hline Winwood et al. [26] & $92^{\mathrm{C}}$ low level & Retro quest & 138 & 32 & 51 & 17 & \\
\hline Winwood et al. [26] & $82^{\mathrm{C}}$ high level & Retro quest & 122 & 31 & 43 & 25 & \\
\hline Winwood et al. [26] & $71^{\mathrm{C}} \leq 105 \mathrm{~kg}$ & Retro quest & 92 & 21 & 53 & 26 & \\
\hline Winwood et al. [26] & $100^{\bar{c}}>105 \mathrm{~kg}$ & Retro quest & 85 & 35 & 47 & 18 & \\
\hline Winwood et al. [26] & $91^{\mathrm{c}} \leq 30 \mathrm{y}$ & Retro quest & 130 & 41 & 45 & 15 & \\
\hline Winwood et al. [26] & $82^{c}>30 y$ & Retro quest & 129 & 25 & 50 & 26 & \\
\hline \multicolumn{8}{|l|}{ Highland games } \\
\hline McLennan et al. [32] & $\begin{array}{l}45 \text { elite }+125 \\
\text { amateur }\end{array}$ & Retro quest & 729 & & & & $\begin{array}{l}67 \text { all injuries } \\
\leq 7 \text { days }\end{array}$ \\
\hline \multicolumn{8}{|l|}{ CrossFit } \\
\hline $\begin{array}{l}\text { Hak et al. } \\
{[33]}\end{array}$ & $\begin{array}{l}93 \mathrm{M} \& 39 \mathrm{~F} \\
\text { open }\end{array}$ & Retro quest & 186 & & & & $\begin{array}{l}7 \text { all injuries } \\
\text { required surgery }\end{array}$ \\
\hline
\end{tabular}

NS Not stated. M Male. F Female. PL Powerlifters. WL Weightlifters. Retro quest Retrospective questionnaire.

a Length of time loss not stated. B Data from 2000. C Number of injured athletes. 
Table 8. Summary of injury causation by training type and/or event.

\begin{tabular}{|c|c|c|c|c|c|}
\hline Study & Athletes & $\begin{array}{l}\text { Study } \\
\text { design }\end{array}$ & $\begin{array}{l}\text { Number } \\
\text { of } \\
\text { injuries }\end{array}$ & Training type/event & $\begin{array}{c}\text { Number and/or } \\
\text { percentage of } \\
\text { injuries/reported } \\
\text { pain }\end{array}$ \\
\hline $\begin{array}{c}\text { Weightlifting } \\
\text { Kulund et al. } \\
\text { [35] }\end{array}$ & $80 \mathrm{M}$ & $\begin{array}{l}\text { Retro } \\
\text { quest }\end{array}$ & 111 & $\begin{array}{l}\text { Clean and Jerk } \\
\text { Deep squats } \\
\text { Snatch } \\
\text { Deadlift } \\
\text { Press }\end{array}$ & $\begin{array}{c}51(46 \%) \\
25(23 \%) \\
23(21 \%) \\
7(6 \%) \\
5(5 \%)\end{array}$ \\
\hline $\begin{array}{l}\text { Powerlifting } \\
\text { Keogh et al. } \\
\text { [20] }\end{array}$ & $\begin{array}{l}82 \text { M \& } 19 \\
F\end{array}$ & $\begin{array}{l}\text { Retro } \\
\text { quest }\end{array}$ & 118 & $\begin{array}{l}\text { Squat/Deadlift/Bench } \\
\text { press } \\
\text { Assistance exercises } \\
\text { Cross training } \\
\text { Unknown }\end{array}$ & $\begin{array}{l}52 \% \\
20 \% \\
13 \% \\
15 \%\end{array}$ \\
\hline $\begin{array}{l}\text { Siewe et al. } \\
\text { [30] }\end{array}$ & $\begin{array}{l}54 \text { M \& } 17 \\
\text { F open \& } \\
\text { elite }\end{array}$ & $\begin{array}{l}\text { Retro } \\
\text { quest }\end{array}$ & & $\begin{array}{l}\text { Squat } \\
\text { Bench Press } \\
\text { Deadlift } \\
\text { Others }\end{array}$ & $\begin{array}{l}65(61 \%)^{\mathrm{a}} \\
60(57 \%)^{\mathrm{a}} \\
33(31 \%)^{\mathrm{a}} \\
43(41 \%)^{\mathrm{a}}\end{array}$ \\
\hline $\begin{array}{l}\text { Raske \& } \\
\text { Norlin [25] }\end{array}$ & $\begin{array}{l}50 \mathrm{M} \& 10 \\
\text { F open elite } \\
\text { PL } \\
50 \mathrm{M} \text { and } 5 \\
\text { F open elite } \\
\text { WL }\end{array}$ & $\begin{array}{l}\text { Retro } \\
\text { quest }\end{array}$ & 254 & $\begin{array}{l}\text { Bench Press } \\
\text { Flies } \\
\text { Dips } \\
\text { Snatch } \\
\text { Clean and Jerk }\end{array}$ & $\begin{array}{l}43 \% \text { and } 44 \%^{\mathrm{b}} \\
47 \% \text { and } 52 \%^{\mathrm{b}} \\
36 \% \text { and } 39 \%^{\mathrm{b}} \\
33 \% \text { and } 31 \%^{\mathrm{b}} \\
33 \% \text { and } 31 \%^{\mathrm{b}}\end{array}$ \\
\hline $\begin{array}{l}\text { Bodybuilding } \\
\text { Eberhardt et } \\
\text { al. } \\
{[38]}\end{array}$ & 250 open M & $\begin{array}{l}\text { Retro } \\
\text { quest }\end{array}$ & 311 & $\begin{array}{l}\text { Bench press } \\
\text { Shoulder press } \\
\text { Squat } \\
\text { Others }\end{array}$ & $\begin{array}{l}16 \% \\
14 \% \\
11 \% \\
59 \%\end{array}$ \\
\hline $\begin{array}{l}\text { Siewe et al. } \\
\text { [31] }\end{array}$ & $\begin{array}{l}54 \text { M \& } 17 \\
\text { F open \& } \\
\text { elite }\end{array}$ & $\begin{array}{l}\text { Retro } \\
\text { quest }\end{array}$ & & $\begin{array}{l}\text { Squat } \\
\text { Bench press } \\
\text { Deadlift } \\
\text { Others }\end{array}$ & $\begin{array}{l}17(24 \%)^{\mathrm{a}} \\
9(13 \%)^{\mathrm{a}} \\
4(6 \%)^{\mathrm{a}} \\
30(42 \%)^{\mathrm{a}}\end{array}$ \\
\hline $\begin{array}{l}\text { Strongman } \\
\text { Winwood et } \\
\text { al. [26] }\end{array}$ & $\begin{array}{l}174^{\mathrm{c}} \text { low \& } \\
\text { high level } \\
\text { M }\end{array}$ & $\begin{array}{l}\text { Retro } \\
\text { quest }\end{array}$ & 268 & $\begin{array}{l}\text { Traditional training } \\
\text { Deadlift } \\
\text { Squats } \\
\text { Overhead press } \\
\text { Bench press }\end{array}$ & $\begin{array}{l}\frac{145(54 \%)}{47(18 \%)} \\
42(16 \%) \\
24(9 \%) \\
16(6 \%)\end{array}$ \\
\hline
\end{tabular}


Weight training injuries

\section{Highland}

Games

McLennan et 45 elite $+\quad$ Retro

al. [32]

125 amateur quest

\section{CrossFit}

Weisenthal et $231 \mathrm{M} \& \quad$ Retro

al. [34] $150 \mathrm{~F} \quad$ quest

open

Traditional other

Strongman training

Stone work

Yoke walk

Tire flip

Farmers walk

Axle work

Log lift/press

Strongman other

729

Highland Games

Weight toss

Caber toss

Hammer throw

Stone throw

Weight for height

$84 \quad$ Crossfit movement

type

Powerlifting

Gymnastics

Olympic lifting

Endurance

Other
$16(6 \%)$

$\underline{123(46 \%)}$

24 (9\%)

21 (8\%)

$16(6 \%)$

12 (5\%)

11 (4\%)

11 (4\%)

$28(10 \%)$

$31 \%$

$25 \%$

$20 \%$

$13 \%$

$11 \%$

19 (23\%)

17 (20\%)

$14(17 \%)$

5 (6\%)

13 (15\%)

M Male. F Female. PL Powerlifters. WL Weightlifters. Retro quest Retrospective questionnaire. a Reported pain as a result of the exercise. b Weight training exercise and shoulder injury association from 1995 and 2000 (respectively). c Number of injured athletes. 


\section{List of Figures}

Figure 1. Illustration of various events/poses in the weight training sports: (a) weightlifting (Carl Pilon), (b) powerlifting (Mitya Galiano), (c) bodybuilding (Amanda Richards), (d) CrossFit (CrossFit Auckland), (e) strongman (Shaun Ellis), and (f) Highland Games (Alain Cadu). Photos reprinted with permission from respective photographers (acknowledged in brackets).

Figure 2. Flow chart of the article selection process.. 


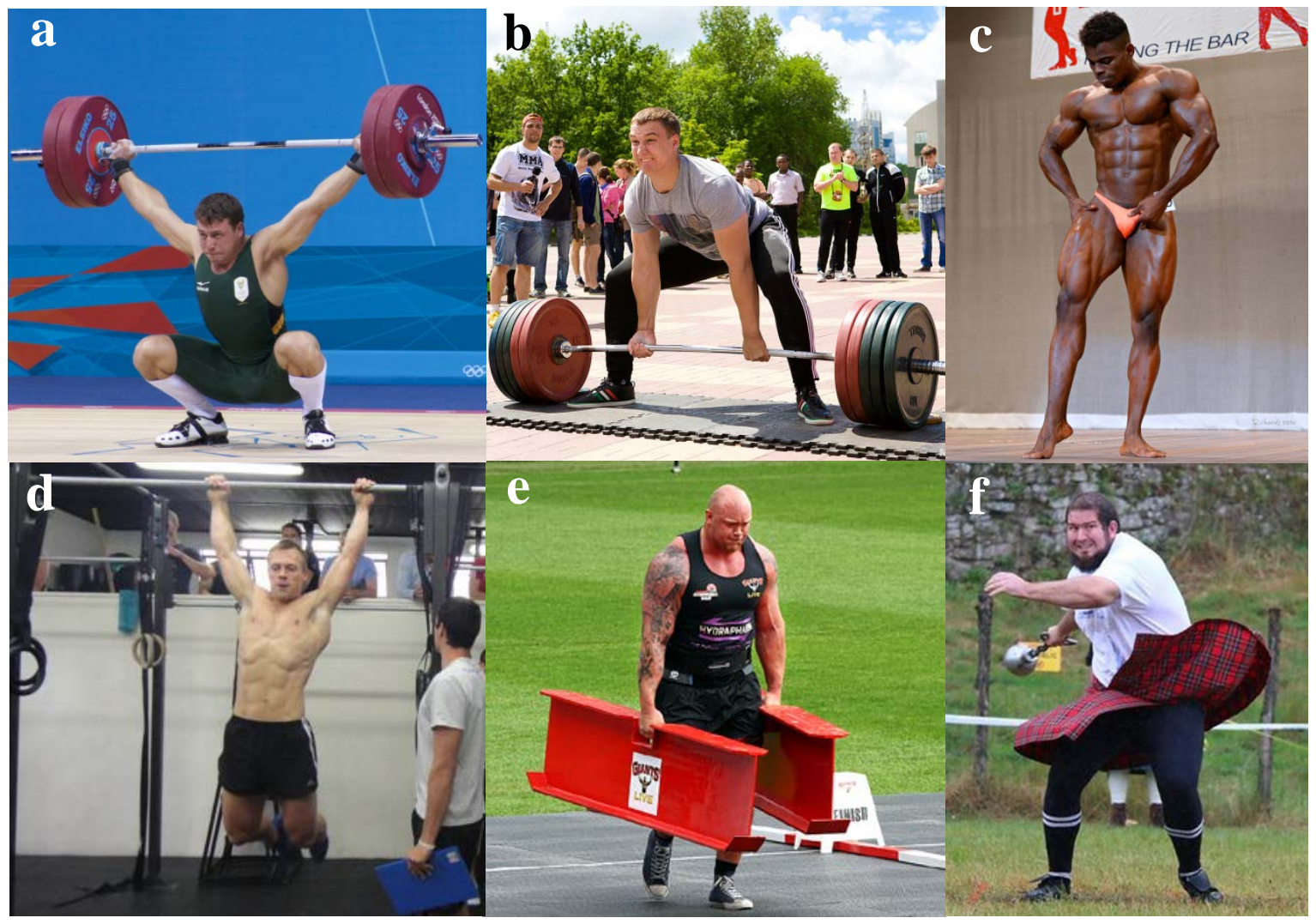

Figure 1. Illustration of various events/poses in the weight training sports: (a) weightlifting (Carl Pilon), (b) powerlifting (Mitya Galiano), (c) bodybuilding (Amanda Richards), (d) CrossFit (CrossFit Auckland), (e) strongman (Shaun Ellis), and (f) Highland Games (Alain Cadu). Photos reprinted with permission from respective photographers (acknowledged in brackets). 


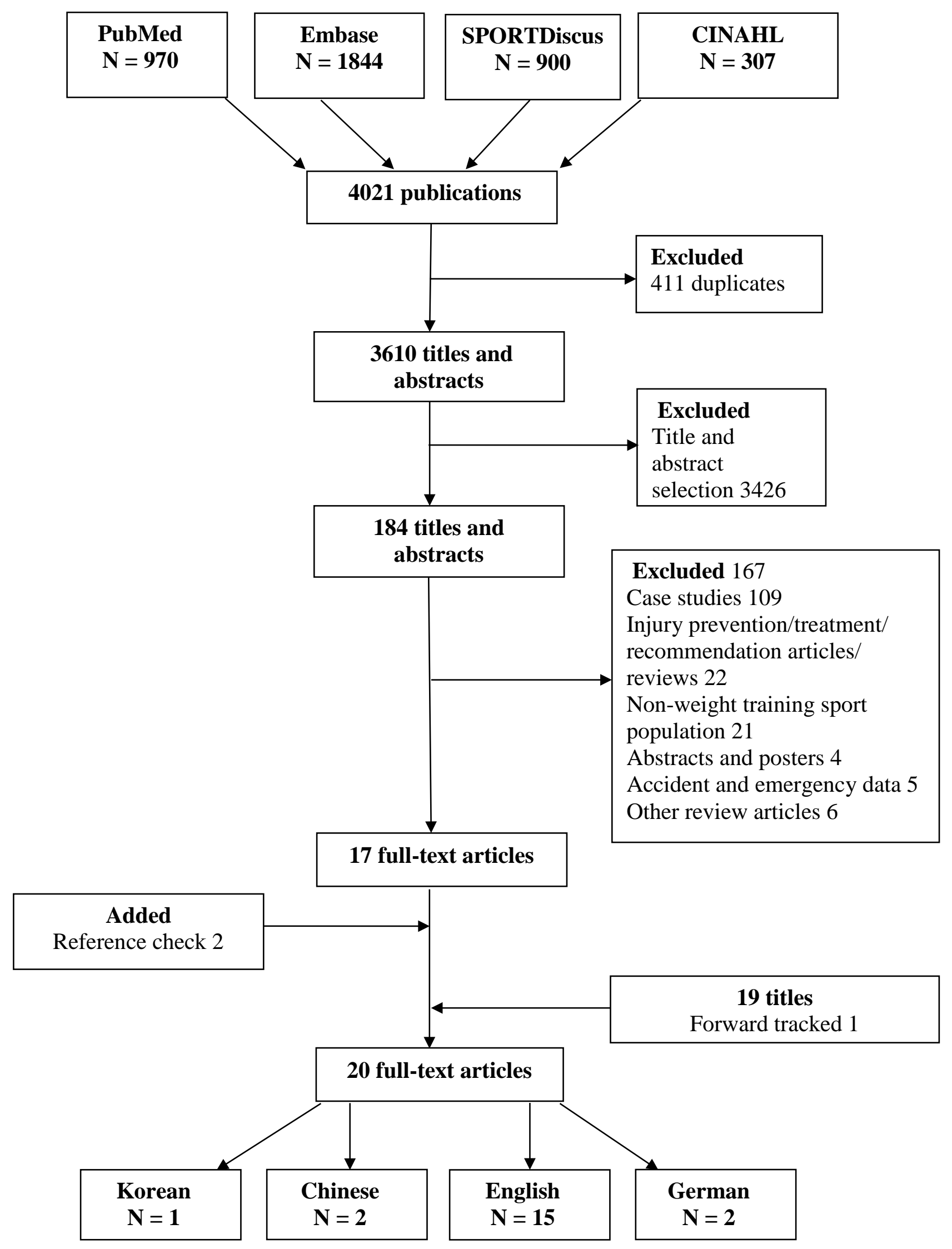

Figure 2. Flow chart of the article selection process 